\title{
The Adsorption Potential and Recovery of Thallium Using Green Micro-Algae from Eutrophic Water Sources
}

\author{
Z.S. Birungi ${ }^{\text {a,1** }}$, E.M.N. Chirwa ${ }^{a}$ \\ ${ }^{a}$ University of Pretoria, Department of Chemical Engineering, Lynnwood Road, Private bag X20 Hatfield, \\ Pretoria 0002, South Africa
}

\begin{abstract}
Thallium (Tl) is a highly volatile and toxic heavy metal regarded to cause pollution even at very low concentrations of several parts per million. Despite the extremely high risk of $\mathrm{Tl}$ in the environment, limited information on removal/recovery exists. The study focussed on the use of green algae to determine the sorption potential and recovery of Tl. From the study, removal efficiency was achieved at $100 \%$ for lower concentrations of $\geq 150 \mathrm{mg} / \mathrm{L}$ of $\mathrm{Tl}$. At higher concentrations in a range of $250-500 \mathrm{mg} / \mathrm{L}$, the performance of algae was still higher with sorption capacity $\left(q_{\max }\right)$ between 830 and $1000 \mathrm{mg} / \mathrm{g}$. Generally, Chlorella vulgaris was the best adsorbent with a high $q_{\max }$ and lower affinity of $1000 \mathrm{mg} / \mathrm{g}$ and $1.11 \mathrm{~L} / \mathrm{g}$ respectively. When compared to other studies on $\mathrm{Tl}$ adsorption, the tested algae showed a better $q_{\max }$ than most adsorbents. The kinetic studies showed better correlation co-efficient of $\leq 0.99$ for Pseudo-second order model than the first order model. Recovery was achieved highest for Chlorella vulgaris using nitric acid at 93.3\%. The strongest functional groups responsible for $\mathrm{Tl}$ binding on the algal cell wall were carboxyl and phenols. Green algae from freshwater bodies showed significant potential for $\mathrm{Tl}$ removal/recovery from industrial wastewater.
\end{abstract}

Key words: green algae, freshwater, cell surface, thallium, adsorption, desorption

\footnotetext{
1 *Corresponding author. Email: zedshariff@yahoo.com; Tel: +27 124204338
} 


\section{Introduction}

Thallium ( $\mathrm{Tl}$ ) is a non-essential and very toxic element often excluded from the list of priority metallic pollutants $[1,2]$. Thallium is regarded to be more toxic to humans than mercury, lead and cadmium and notable for causing occupational, accidental and environmental hazards [3,4]. Thallium appears in two oxidation states; Tl (I) which is highly soluble in aqueous environments and resembles alkali metals and $\mathrm{Tl}$ (III) which is more stable forming complexes with sulphates, chlorides, carbonates and nitrates [5-7]. Thallium deposits are generally scarcely distributed worldwide with many industrial applications such as catalyst for making certain alloys, molecular probes, thermometers, acusto-optical equipment, optical glass with refractive index, imitation jewellery, scintillation counters, and super-conductivity in ceramic compounds $[8,9]$.

One of the major concerns of $\mathrm{Tl}$ toxicity lies in the similar ionic radii of $\mathrm{Tl}^{+}$and monovalent cations especially potassium $\left(\mathrm{K}^{+}\right)$in the crystal lattice which affects all organic ligands. In this case, the cell membrane has non- discriminatory uptake of $\mathrm{Tl}^{+}$over $\mathrm{K}^{+}$which alters the proper functioning of the biochemical reactions, for example pyruvate kinase, ATPase, stabilisation of ribosomes $[4,10,11]$. Thallium has been reported to cause acute and chronic poisoning with effects such as degenerative changes in the heart, liver and kidney, damage of the central nervous and cardiovascular systems, psychosis, insomnia, alopecia, peripheral neuropathy, gastroenteritis [12-14].

Previous research on removal technologies has focussed on using pre-concentration of $\mathrm{Tl}$ by chelating resins [15]; oxidative precipitation of thallichydroxide, reductive cementation of thallium; chemical precipitation by hydroxide compounds, solvent extraction using tributyl phosphate (TBP), trioctyl phosphine oxide (TOPO) [16, 17]; extraction by complex forming re-agents [18]. U.S.EPA approved various treatment technologies such as activated alumina and ion exchange for removal of thallium but the methods are seemingly costly and ineffective [19].

Biosorption is an alternative and or complementary method which utilises relatively cheap waste biomass for sequestering of heavy metals. A variety of microorganisms like bacteria and algae have been utilised in biosorption of some common heavy metals with the exception of $\mathrm{Tl}[20,21]$. Information on the occurrence, mechanisms, behaviour, and bioremediation of thallium toxicity in the environment is still sketchy $[18,22]$. Micro-algae especially green 
algae has over 500 genera and approximately 15,000 species found mainly in freshwater of which a few were investigated for their biosorption potential [23, 24]. This study focused on the biosorption potential of 3 green algal species from eutrophic freshwater bodies. Equilibrium and kinetic models were used to estimate the sorption potential and the rate of reaction respectively.

\section{0 Experimental}

\subsection{Algal Isolation and Culture}

Algal samples were sourced from Hartbeespoort dam, a freshwater body in South Africa. The algae was centrifuged and washed several times with double distilled water to obtain a sterile concentrate. Agar plates were prepared from bacteriological agar and AF-6 media using standard procedures by [25]. The algae was streaked on the agar plates and left to grow for seven days. Repeated plating was done to eliminate bacteria and obtain pure colonies representing a single species. The algal species were identified using $18 \mathrm{~S}$ ribosomal RNA gene and the species identified through BLAST search. The identified species included Scenedesmus acuminutus, Chlorella vulgaris and Chlamydomonas reinhardtii. The unialgal species were inoculated into AF-6 media and cultured in the laboratory as starter cultures under controlled temperature at $21-23^{\circ} \mathrm{C}$ and algal light (Osram L $36 \mathrm{~W} / 77$ Floura). The algae were then sub-cultured in conical flasks of 1000 and $2000 \mathrm{ml}$ to increase the surface area and volume of algal growth. Harvesting was done twice every month, centrifuged and washed twice in double distilled water to remove excess nutrients. The samples were then dried in the oven at $50^{\circ} \mathrm{C}$ overnight and stored for sorption experiments.

\subsection{Sample Preparation and Isotherm Experiments}

The algal samples were crushed in a mortar to form a powder and screened through a $0.3 \mathrm{~mm}$ sieve to obtain a uniform size and increase the surface area for adsorption. All chemicals used were of analytical grade and purchased from Merck and Laboratory consumables and chemical supplies in South Africa. Tl is very toxic especially through inhalation and contact with skin or eyes, and was therefore handled with care using the Material Safety Data Sheet (MSDS). The safety gear used in the laboratory included a lab coat, safety goggles, latex gloves and foot wear. All experiments containing Tl were carried out in fume hoods and the wasted disposed in a labelled container. After handling of Tl, soap and water was used to thoroughly clean the hands. A standard stock solution of $1000 \mathrm{mg} / \mathrm{L} \mathrm{of} \mathrm{Tl}^{+}$was used to 
prepare initial Thallium concentrations between $15-500 \mathrm{mg} / \mathrm{L}$. The initial $\mathrm{Tl}$ concentrations were measured into $100 \mathrm{ml}$ Erlenmeyer volumetric flasks. The $\mathrm{pH}$ of the solution was kept constant at 6 using $0.1 \mathrm{M} \mathrm{NaOH}$ and $\mathrm{HCl}$ for equilibrium experiment. The weighted biomass of $50 \mathrm{mg}$ was added to the measured $\mathrm{Tl}$ concentrations and stirred on a magnetic stirrer at a constant speed of $350(\mathrm{rpm})$ for 6 hours. The effect of $\mathrm{pH}$ was also studied under constant conditions at initial concentration of $250 \mathrm{mg} / \mathrm{L}$ and a biomass of $80 \mathrm{mg}$ in the $\mathrm{pH}$ range of 2-8 for 4 hours. The experiment was carried out in duplicates and control set up. The $\mathrm{pH}$ was adjusted hourly to optimum. A sample was drawn, centrifuged and the supernatant analysed using Inductively Coupled Plasma (ICP, Spectro Arcos FHS12, oschstroisse, Germany).

\subsection{Kinetics of Thallium Removal and Recovery}

The effect of initial concentration and contact time on $\mathrm{Tl}$ adsorption was tested. A constant biomass of $50 \mathrm{mg}$ and initial $\mathrm{Tl}$ concentration in the range of $250-500 \mathrm{mg} / \mathrm{L}$ was used for all the algal species. The weighted algal samples were mixed in the $\mathrm{Tl}$ solution and stirred on a magnetic stirrer at room temperature and a constant speed of $350 \mathrm{rpm}$. Samples were taken at known time intervals, centrifuged at $6000 \mathrm{rpm}$ for 10 minutes and the supernatant analysed using ICP. The algae logged with $\mathrm{Tl}$ from equilibrium experiments were used for desorption kinetics. The samples were rinsed twice in deionised water and added to $0.1 \mathrm{M}$ nitric acid concentration for recovery. Samples were also drawn at set time intervals and the supernatant analysed using ICP.

\subsection{Algal Characterisation}

The algal samples were characterised using the Fourier Transform Infrared Spectroscopy (FTIR- Nicolet iS5, Thermo, South Africa) and Scanning Electron Microscopy (SEM, JOEL JSM 5800LV, Tokyo, Japan). The FTIR sample holder was first cleaned using acetone and a background spectrum collected to check the performance of the instrument. A sample was then loaded and the sample spectrum obtained. Data processing was done to transform absorbance into \% transmittance showing wavelength peaks.

Sample preparation for SEM was carried out using $0.5 \%$ aqueous osmium tetroxide and phosphate buffer at a concentration of $0.05 \mathrm{M}$ for 1 hour. The buffer was used to protect the biological sample from becoming acidic. Water was then extracted from the sample using a range of ethanol grades from 30-100\%. The final rinsing was done three times with anhydrous ethanol. Critical drying point using liquid carbon dioxide was then used for sample 
drying to prevent damaging the sample. The sample was then mounted on stubs and then coated with gold. After sample preparation, SEM was used to obtain images at different magnification before and after adsorption.

\section{Results and Discussion}

\subsection{Isotherm Modelling}

The Langmuir and Freundlich models were used to fit experimental data using linearised equation 1 and 2 respectively. These models are widely accepted and often used in biosorption studies involving single solute systems [26-28]. The linearised graph $C_{e} / q_{e}$ vs. $C_{e}$ for Langmuir model and $\log q_{e}$ vs. $\log C_{e}$ for Freundlich model was plotted for all the tested algae, Fig. 1 and 2. The models were compared and the Langmuir model generally exhibited a better correlation co- efficient $\left(R^{2}\right)$ of $\leq 0.99$ as compared to the Freundlich model with $\leq$ 0.94 for all the 3 tested species. The slope and intercept were calculated from the linearised equations for sorption capacity $\left(q_{\max }\right)$ and affinity of the metal $(b)$. The Langmuir, 1916 [29] is expressed by the linearised equation;

$$
C_{e} / q_{e}=C_{e} / q_{\max }+1 / b q_{\max }
$$

where $q_{e}$ is the adsorbed metal at equilibrium $(\mathrm{mg} / \mathrm{g}), q_{\max }$ is the maximum amount of metal sorbed $(\mathrm{mg} / \mathrm{g}), \quad b$ is a constant related to the energy of sorption and $C_{e}$ is the equilibrium metal ion concentration $(\mathrm{mg} / \mathrm{L})$.

The Freundlich, 1906 [30] is represented by the linearised equation as follows;

$\log q_{e}=\log k+1 / n \log C_{e}$

where $k$ is biosorption equilibrium constant, representative of the sorption capacity and $n$ is a constant indicative of biosorption intensity

The essential characteristics of Langmuir were expressed using a dimensionless constant separation factor, $R_{L}[31]$.

$$
R_{L}=\frac{1}{1+\left(1+b_{L} C_{o}\right)}
$$


where $R_{L}$ is the separation factor; $b_{L}$ constant related to energy of adsorption from Langmuir model $(\mathrm{L} / \mathrm{g}) ; C_{o}$ is the highest initial concentration $(\mathrm{mg} / \mathrm{L})$

Chlamydomonas reinhardtii and Chlorella vulgaris had the highest $q_{\max }$ of $1000 \mathrm{mg} / \mathrm{g}$ but the latter expressed a lower affinity $(b)$ of $1.11 \mathrm{~L} / \mathrm{g}$ compared to the former with $1.67 \mathrm{~L} / \mathrm{g}$, Table 1. Scenedesmus acuminutus had both high $q_{\max }$ and lowest $b$ of $833.3 \mathrm{mg} / \mathrm{g}$ and 0.290 $\mathrm{L} / \mathrm{g}$ respectively. Depending on the interest of the study, biosorbents with a higher $q_{\max }$ and a lower $b$ are reported to be better adsorbents regardless of recovery levels [28, 32, 33]. Biosorbents with both a high $q_{\max }$ and a high $b$ usually have a better efficiency for recovery [34]. The Langmuir isotherm was further evaluated using a separation factor, $R_{L}$ given by the equation (Eq. 3.7). When $R_{L}$ is $>1$ then it's unfavourable and favourable if $0<R_{L}<1$ [35]. $R_{L}$ was calculated for all the tested algae and found to be favourable for adsorption for all the species, Table 1 .

The tested algal species were compared with some other potential adsorbents for $\mathrm{Tl}$ removal. All the 3 tested algal species had significant $q_{\max }$ in a range of $830-1000 \mathrm{mg} / \mathrm{g}$ compared to most adsorbents tested for thallium removal except for Prussian blue NP (PB) which had $1400 \mathrm{mg} / \mathrm{g}$, Table 2. The high binding capacity for PB could be attributed to the physical chemical properties of the reaction medium such as particle size, moisture content and is usually used as an antidote for $\mathrm{Tl}$ poisoning [36]. 

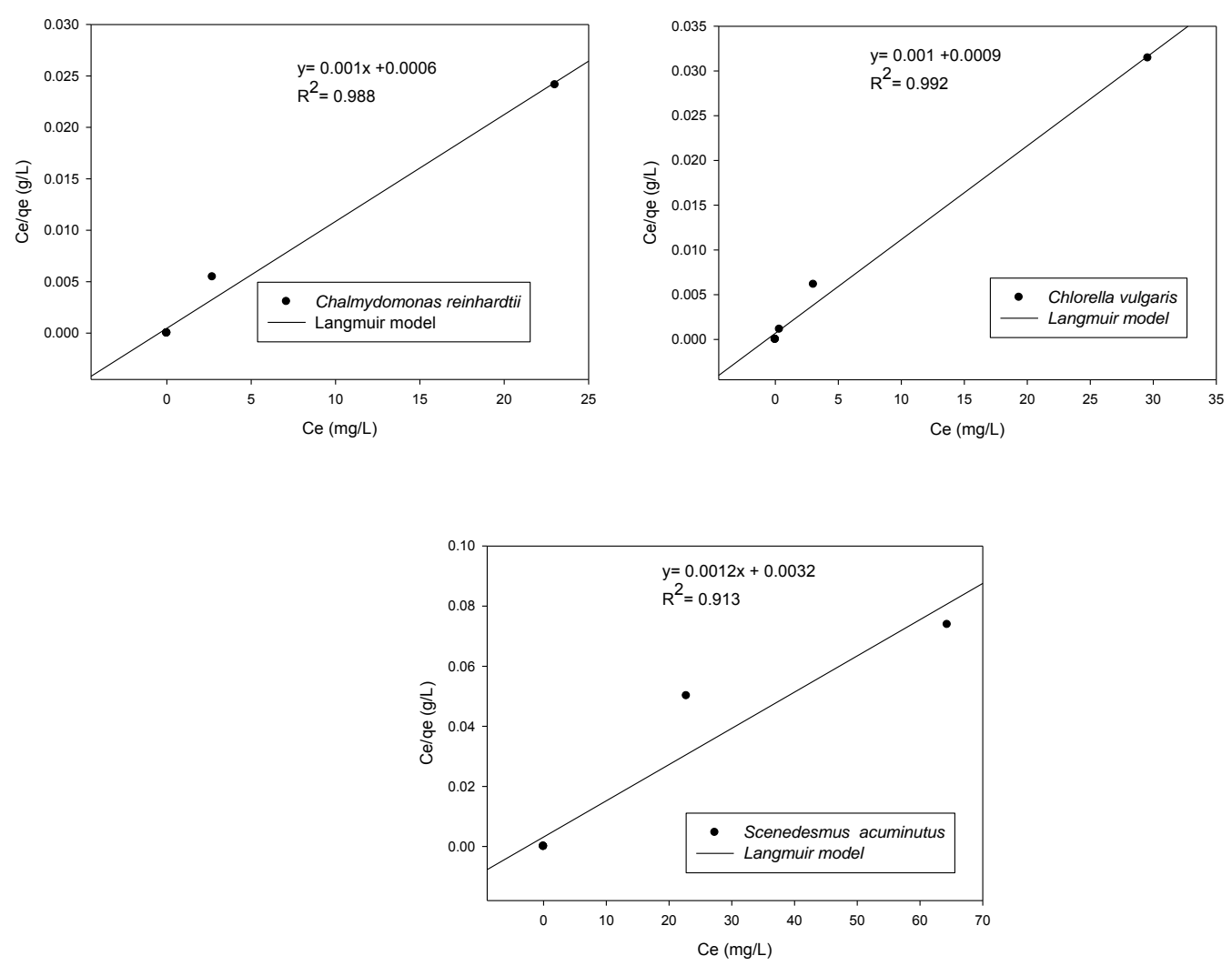

Figure 1: Linearised models of Langmuir for C. vulgaris, C.reinhardtii, S. acuminutus
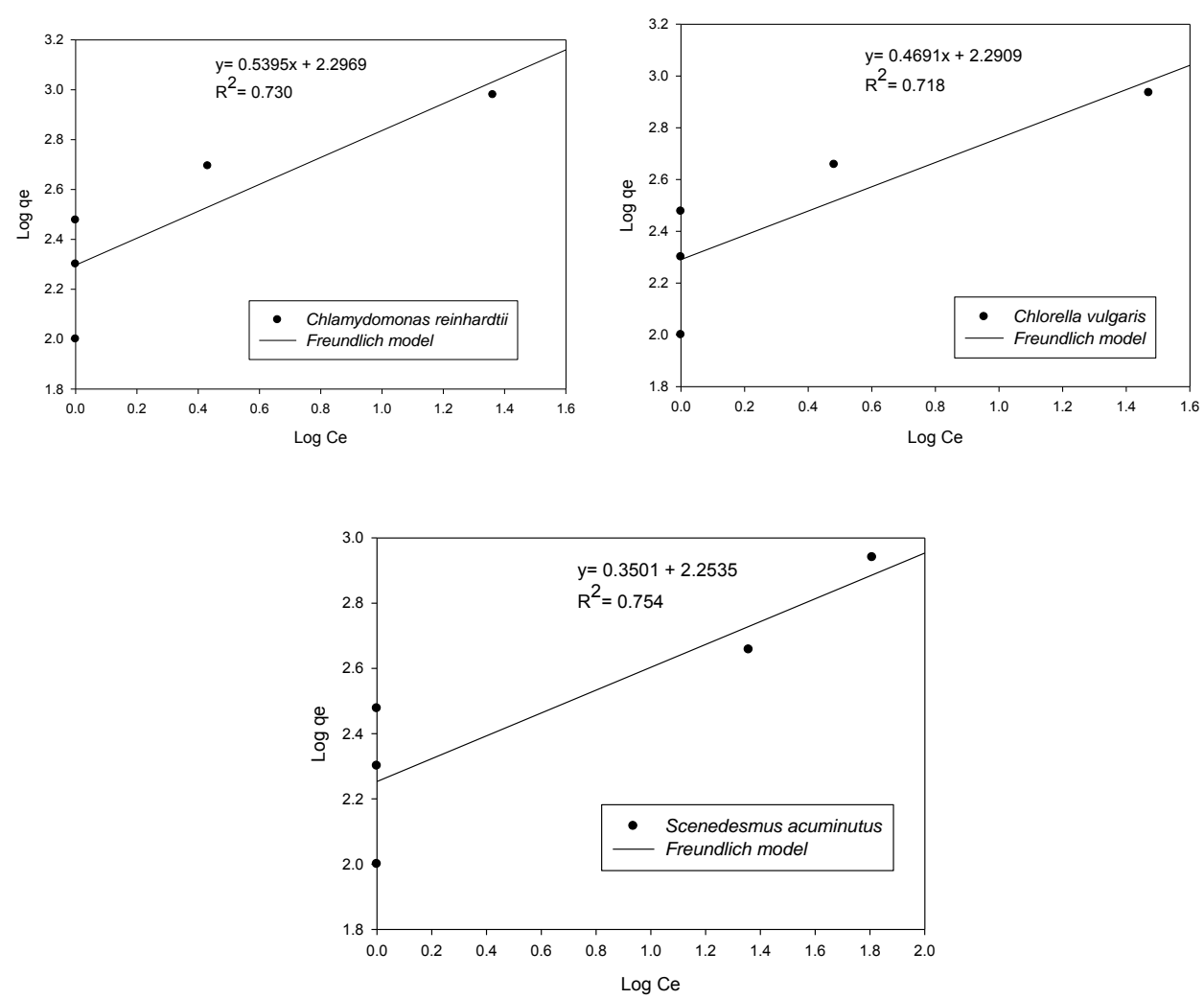

Figure 2: Linearised models of Freundlich for C. vulgaris, C.reinhardtii, S. acuminutus, 
Table 1: Model constants and regression coefficients for Langmuir and Freundlich isotherms

\begin{tabular}{lccccccc}
\hline Algal species & \multicolumn{3}{c}{ Langmuir constants } & \multicolumn{5}{c}{ Freundlich constants } \\
\hline & $q_{\max }(\mathbf{m g} / \mathbf{g})$ & $b(\mathbf{L} / \mathbf{g})$ & $R_{L}$ & $R^{2}$ & $n$ & $K$ & $R^{2}$ \\
Chlorella vulgaris & 1000 & 1.111 & 0.0018 & 0.992 & 2.132 & 9.884 & 0.718 \\
Scenedesmus acuminutus & 833.33 & 0.290 & 0.0069 & 0.907 & 2.856 & 9.521 & 0.754 \\
Chlamydomonas reinhardtii & 1000 & 1.667 & 0.0012 & 0.987 & 1.854 & 9.943 & 0.730 \\
& & & & & & &
\end{tabular}

Table 2: Comparison of adsorption capacity of $\mathrm{Tl}$ using tested algae with other adsorbents

\begin{tabular}{lll}
\hline Adsorbent & $q_{\max }(\mathbf{m g} / \mathbf{g})$ & References \\
\hline Sodium Polystyrene sulfonate & 713 & {$[37]$} \\
Modified sugar beet pulp & 185.2 & {$[38]$} \\
Pistachio hull & 125 & {$[39]$} \\
Prussian blue NP & 1400 & {$[36]$} \\
Activated coal & 59.7 & {$[38]$} \\
Modified eucalyptus & 80.65 & {$[40]$} \\
Alginate- PB & 103 & {$[41]$} \\
Saw dust & 13.18 & {$[40,42]$} \\
Peat & 24.14 & {$[43]$} \\
Modified tree leaves & 54.6 & {$[44]$} \\
Scenedesmus acuminutus & 833.33 & Current study \\
Chlorella vulgaris & 1000 & Current study \\
Chlamydomonas reinhardtii & 1000 & Current study \\
\hline
\end{tabular}

\subsection{Adsorption Affinity of Tl on Tested Algae}

The adsorption affinity of metals can be determined using the distribution co- efficient $\left(K_{d}\right)$ which expresses the effectiveness of the biosorbent for metal uptake. The higher the $K_{d}$, the stronger the binding affinity of the sorbents to sorbate. When the $K_{d}$ value is more than 5000 $\mathrm{mL} / \mathrm{g}$, then it's considered good, and when the value is greater than $50000 \mathrm{~mL} / \mathrm{g}$ then its excellent $[45,46]$. The $K_{d}$ was calculated using equation (Eq. 4) for all the tested algae. The adsorption affinity of the metal using biosorbents can be expressed using the distribution coefficient, $K_{d}$ as indicated below. 


$$
K_{d}=\frac{\left(C_{o}-C_{f}\right)}{C_{f}} \times \frac{V}{M}
$$

where $C_{o}$ is the initial concentration, $C_{f}$ is final concentrations $(\mathrm{mg} / \mathrm{L}) ; \quad V$ is the volume of solution (ml); $M$ is the weight of algae $(\mathrm{g})$.

Chlorella vulgaris and Chlamydomonas reinhardtii had significantly high $K_{d}$ values of 45934 and $41458 \mathrm{~mL} / \mathrm{g}$ respectively at initial concentration of $500 \mathrm{mg} / \mathrm{L}$ which was very close to excellent value given, Table 3 . The $K_{d}$ value for Scenedesmus acuminutus was also good with $19945 \mathrm{~mL} / \mathrm{g}$ greater than 5000. All the species confirmed to have a strong binding affinity for $\mathrm{Tl}$.

Table 3: Distribution co-efficient for removal of Tl using 3 test algae

\begin{tabular}{llll}
\hline Species & $C_{o}(\mathbf{m g} / \mathbf{L})$ & $C_{f}(\mathbf{m g} / \mathbf{L})$ & $K_{d}(\mathbf{m L} / \mathbf{g})$ \\
\hline Scenedesmus acuminutus & 250 & 22.784 & 19945.23 \\
& 500 & 64.350 & 13540.02 \\
Chlorella vulgaris & 250 & 28.043 & 15829.76 \\
& 500 & 20.862 & 45934.04 \\
Chlamydomonas reinhardtii & 250 & 16.221 & 28825.19 \\
& 500 & 23.011 & 41457.48 \\
\hline
\end{tabular}

\subsection{Effect of Initial Concentration on Removal of TI}

The effect of initial concentration on removal of $\mathrm{Tl}$ was studied in the range of $50-500 \mathrm{mg} / \mathrm{L}$ for three algal species. At very low concentration $\leq 150 \mathrm{mg} / \mathrm{L}$, there was complete efficiency with $100 \%$ uptake in less than 5 minutes for all the species. At higher concentrations, maximum uptake was still attained in the first 25 minutes with initial concentration between $250-500 \mathrm{mg} / \mathrm{L}$ reduced $\leq 55 \mathrm{mg} / \mathrm{L}$, Fig. 3. Fluctuations in the removal of $\mathrm{Tl}$ were observed in the preceding period until equilibrium was attained which could be due to saturation of some active functional groups. Chlorella vulgaris showed the highest removal rate at $95.83 \%$ followed by Chlamydomonas reinhardtii at $95.4 \%$ in a period of 6 hours. 


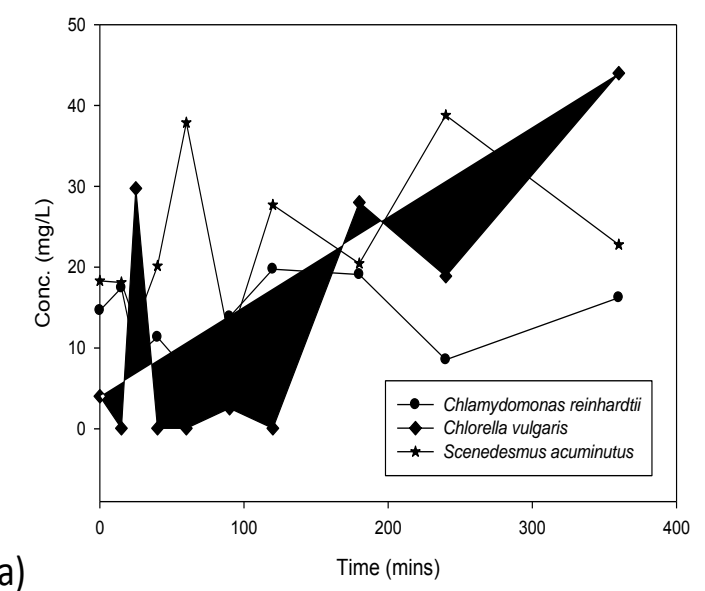

a)

Figure 3: Dependence of high initial thallium concentration with time for the 3 algal species, a) at $250 \mathrm{mg} / \mathrm{L}$ and b) at $500 \mathrm{mg} / \mathrm{L}$

\subsection{Effect of pH on Removal of Tl}

The variation in solution $\mathrm{pH}$ is an important factor which influences the binding of protons and cation for the active sites on the adsorbent [47, 48]. At low $\mathrm{pH}$ of 2 , there was a generally low uptake of $\mathrm{Tl}$ for all tested species, Fig 4. At lower $\mathrm{pH}$, the hydrogen ions $\left(\mathrm{H}^{+}\right)$are in excess and compete with $\mathrm{Tl}^{+}$for the functional groups on the algae. When the $\mathrm{pH}$ was increased to 4, uptake also increased due to deprotonation of active sites. At $\mathrm{pH}$ of 5, uptake increased for Chlamydomonas reinhardtii and Scenedesmus acuminutus but reduction was observed for Chlorella vulgaris. Between $\mathrm{pH}$ of 5 and 6, there was no significant change in uptake except an increase was observed for Chlorella vulgaris, Fig. 4. The sorption of $\mathrm{Tl}$ in other studies was also found to increase with an increase in $\mathrm{pH}[19,49]$. The results indicated optimal $\mathrm{pH}$ to be between 5 and 6 for $\mathrm{Tl}$ adsorption. At $\mathrm{pH}$ above 7, there was a general reduction in removal except for Chlamydomonas reinhardtii which showed a minimal increase in uptake. At very high $\mathrm{pH}$, precipitation usually occurs inhibiting any further uptake hence reduction in sorption. 


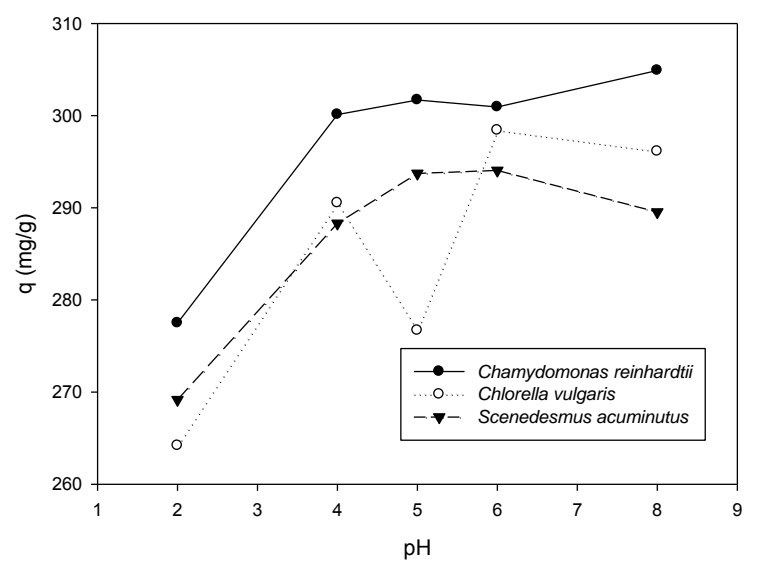

Figure 4: Effect of $\mathrm{pH}$ on uptake of $\mathrm{Tl}$ for all tested algae

\subsection{Adsorption Kinetic Model for Thallium Removal}

Kinetic models assist in understanding the adsorption mechanisms caused by variation in experimental conditions. In this study, the first and Pseudo- second order kinetic models were tested on 3 algal species. The linearised equations for first and Pseudo-second order model were used to estimate the slope and intercept, Eq. 5 and 6. The first-order rate expression of Lagergren, 1898 [50] is given by the linearised equation as follows;

$\log \left(q_{e}-q_{t}\right)=\log q_{e}-{ }^{k} 1 / 2.303^{t}$

Pseudo second order equation of [51] is given by the following linearised form;

$$
t / q_{t}=1 / k_{2} q_{e}^{2}+1 / q_{e} t
$$

where, $q_{t}$ is the amount of adsorbed metal on the algal biomass at time (t) in $(\mathrm{mg} / \mathrm{g}) ; q_{e}$ is the equilibrium sorption uptake $(\mathrm{mg} / \mathrm{g}) ; k_{l}$ the rate constant of Lagergren first-order adsorption $\left(\min ^{1}\right)$ and $k_{2}$ is the rate constant of second-order adsorption.

The first order model fit well with only a few data points in the first 10 minutes and then the experimental data became scattered with a very low correlation co-efficient for the rest of the period. The experimental data fit well with the Pseudo-second order model with $R^{2}$ of $\geq 0.99$ at initial concentrations of 250 and $500 \mathrm{mg} / \mathrm{L}$ of $\mathrm{Tl}$, Fig. $5 \mathrm{a}$ and $5 \mathrm{~b}$. In other studies on biosorption of heavy metals the Pseudo-second order model fit better than the first order model [52-54]. 
Additional evidence for preference of Pseudo- second order model was provided in Table 4 with no pronounced difference between experimental $q_{\text {exp }}$ and calculated $q_{\text {cal }}$ data especially at initial concentration of $250 \mathrm{mg} / \mathrm{L}$. At higher concentrations of $500 \mathrm{mg} / \mathrm{L}$, the difference was slightly greater between $q_{\exp }$ and $q_{\text {cal }}$. This could be attributed to the rate of chemical reaction $k_{2}$ observed to be high especially for Chlorella vulgaris and Chlamydomonas reinhardtii at 0.002 and $0.001 \mathrm{~min}^{-1}$ respectively.
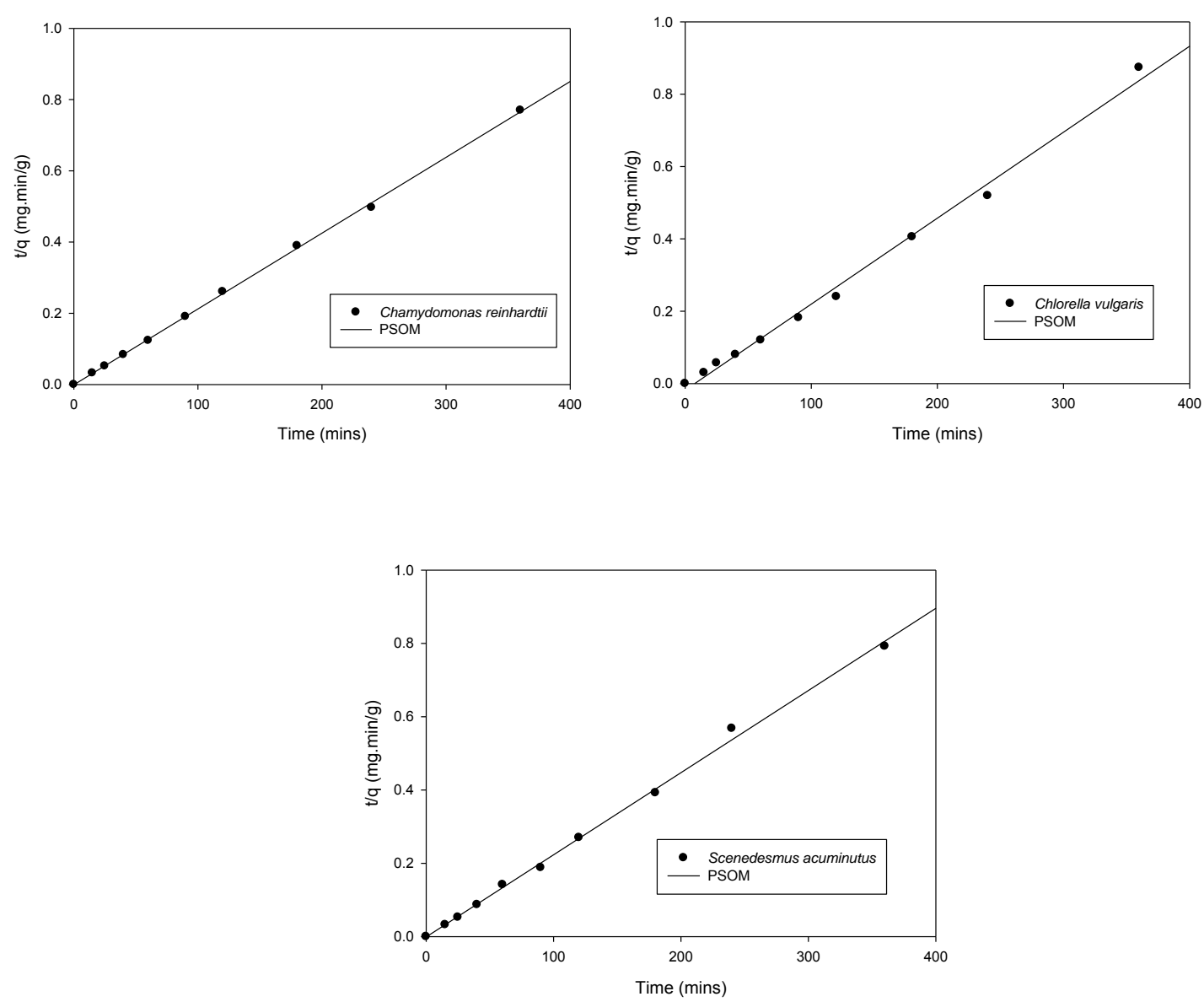

Figure 5a: Linearised plots of Pseudo- second order kinetic model for 3 algal species at $250 \mathrm{mg} / \mathrm{L}$ 

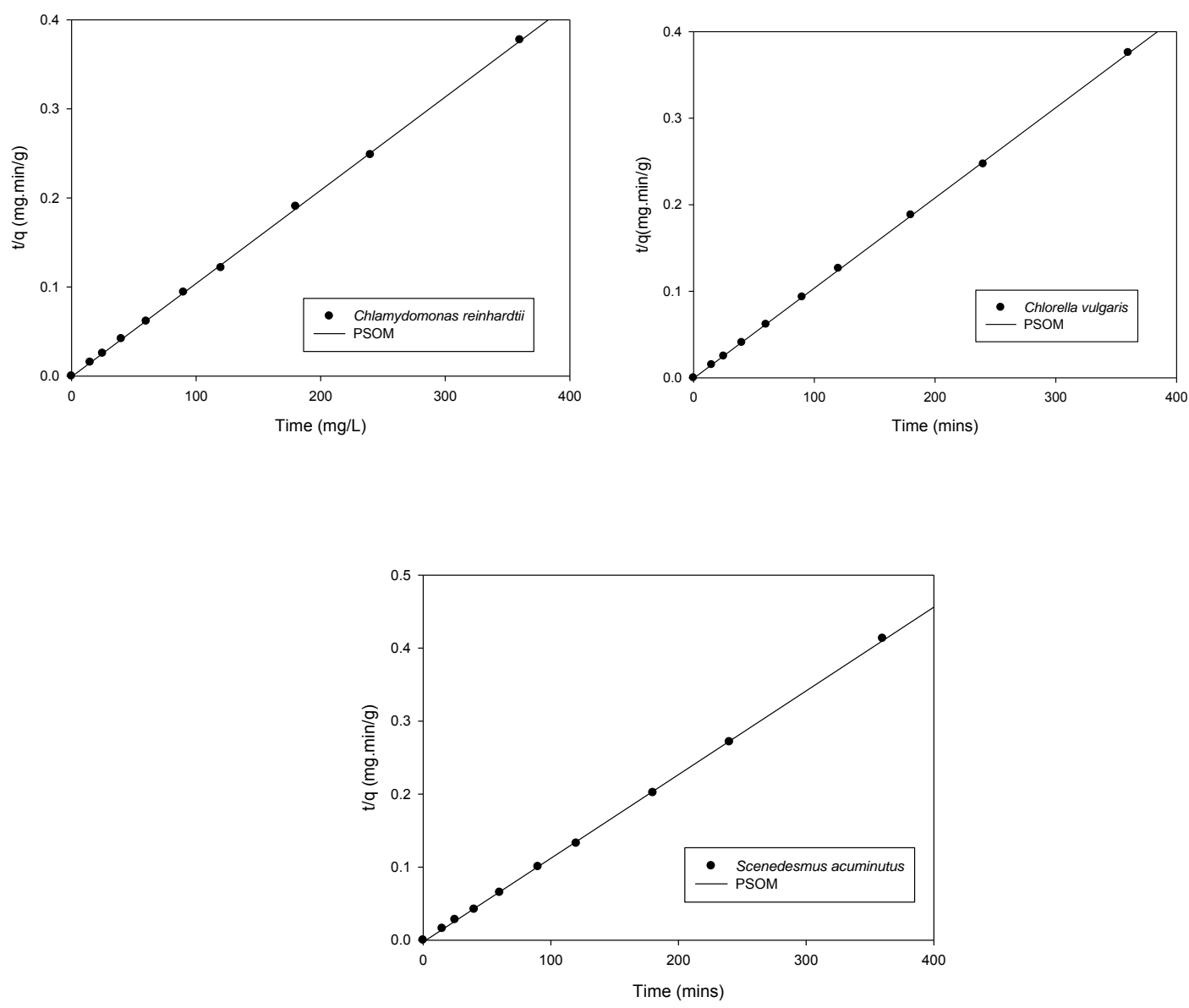

Figure 5b: Linearised plots of Pseudo- second order kinetic model for 3 algal species at $500 \mathrm{mg} / \mathrm{L}$

Table 4: Pseudo-second order adsorption kinetic parameters for all the tested algae at concentrations of 250 and $500 \mathrm{mg} / \mathrm{L}$ for Thallium

\begin{tabular}{llllll}
\hline Algal species & $\boldsymbol{c}_{\boldsymbol{i}}$ & $\boldsymbol{k}_{2}$ & $\boldsymbol{R}^{2}$ & $\boldsymbol{q}_{\text {exp }}$ & $\boldsymbol{q}_{\text {cal }}$ \\
& $(\mathbf{m g} / \mathbf{L})$ & $\mathbf{m i n}^{-1}$ & & $(\mathbf{m g} / \mathbf{g})$ & $(\mathbf{m g} / \mathbf{g})$ \\
\hline Scenedesmus acuminutus & 250 & 0.00084 & 0.998 & 454.432 & 454.546 \\
Chlorella vulgaris & 250 & 0.00032 & 0.994 & 412.005 & 416.67 \\
Chlamydomonas reinhardtii & 250 & 0.0074 & 0.9995 & 467.559 & 476.191 \\
& & & & & \\
Scenedesmus acuminutus & 500 & 0.000484 & 0.999 & 871.300 & 909.091 \\
Chlorella vulgaris & 500 & 0.002 & 0.999 & 958.276 & 1000 \\
Chlamydomonas reinhardtii & 500 & 0.00143 & 0.9998 & 953.978 & 1000 \\
\hline
\end{tabular}

\subsection{Effect of Contact Time on Thallium Recovery}

The recovery of $\mathrm{Tl}$ was a much slower process than its uptake in the 3 tested algal species.

The desorption efficiency was very low in the first 360 minutes with less than $40 \%$ recovery 
for all the algal species. This could be due to the formation of very strong complexes of $\mathrm{Tl}$ with the active functional groups which were not easily released. After 16 hours, the percentage recovery doubled for Scenedesmus acuminutus and Chlorella vulgaris to $\geq 66 \%$ respectively. In a period of 24 hours, there was a significant recovery of $\mathrm{Tl}$ with $93.26 \%$ and $85.52 \%$ achieved for Chlorella vulgaris and Scenedesmus acuminutus, Fig.6. Chlamydomonas reinhardtii had the lowest recovery rate of $57.49 \%$ in the same period. The results implied that given more time, there is possibility of total recovery for some species. Some studies indicated that essentially all Thallium was recovered due to the cation exchange mechanism (reversible) as opposed to the precipitation or absorption $[55,56]$.

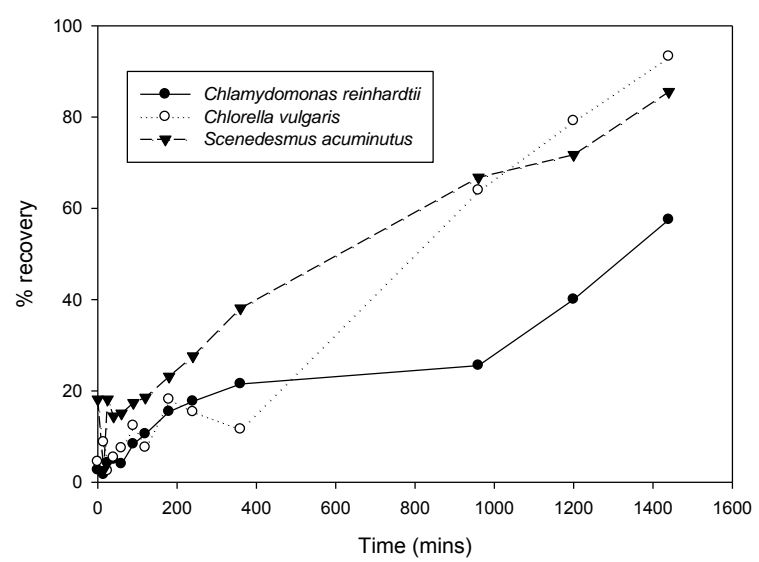

Figure 6: Efficiency of $\mathrm{Tl}$ recovery for Chlorella vulgaris, Chlamydomonas reinhardtii and Scenedesmus acuminutus at initial concentration of $250 \mathrm{mg} / \mathrm{L}$

\subsection{Desorption Kinetic Model for Thallium Removal}

The modified desorption kinetic models of first order and Pseudo- second order model were used to estimate the rate of recovery (57). The slope and intercept were estimated from the following desorption Eqns. 7, 8 and 9.

$$
d q / d t=-k_{1, d e s} q
$$

The modified $2^{\text {nd }}$ order rate equation assumes the rate of desorption is proportional to the square of $\mathrm{Tl}$ filled sites and is given by differential Eq.;

$$
d q / d t=-k_{2, d e s} q^{2}
$$


where $k_{1}$ is the $1^{\text {st }}$ order desorption rate constant; $q$ is the remaining amount of metal bound to the biomass at time $t ; k_{2}$ is $2^{\text {nd }}$ order desorption rate constant. The differential equations 7 and 8 were integrated using the following Eq.;

$q_{n+1}=q_{n}-(d q / d t)_{n}\left(t_{n+1}-t_{n}\right)$

where $\boldsymbol{q}_{n}$ is the amount of $\mathrm{Tl}$ remaining in algae at time $t_{n}$ and $q_{n+1}$ is the amount of $\mathrm{Tl}$ at time $\boldsymbol{t}_{\boldsymbol{n}}$ minus the rate of desorption multiplied by the incremental time step, $k_{l}$ the rate constant of modified first-order desorption $\left(\mathrm{min}^{-1}\right)$ and $k_{2}$ is the rate constant of modified second-order desorption.

In the modified first order model the data fit only for the first 15 minutes for the 3 tested algal species. Generally the modified Pseudo-second order had a higher $R^{2} \geq 0.99$ compared to the first order model. In addition, there was no pronounced difference between the experimental $\left(q_{n}\right)$ and calculated $\left(q_{n+1}\right)$, Table 5. Njikam and Schiewer, 2012 [57] also found that the modified Pseudo-second order showed a better fit compared to modified first order model.

Table 5: Modified Pseudo-second order kinetic model parameters

\begin{tabular}{llllll}
\hline Algal species & $\begin{array}{l}\boldsymbol{C}_{\boldsymbol{i}} \\
(\mathrm{mg} / \mathbf{L})\end{array}$ & $\begin{array}{l}\boldsymbol{k}_{\mathbf{2}, \text { des }} \\
\left(\mathrm{Min}^{-1}\right)\end{array}$ & $R^{2}$ & $\begin{array}{l}\boldsymbol{q}_{\boldsymbol{n}} \\
(\mathrm{mg} / \mathrm{g})\end{array}$ & $\begin{array}{l}\boldsymbol{q}_{\boldsymbol{n}+\mathbf{1}} \\
(\mathrm{mg} / \mathrm{g})\end{array}$ \\
\hline $\begin{array}{l}\text { Chlamydomonas reinhardtii } \\
\text { Chlorella vulgaris }\end{array}$ & 250 & 0.000002 & 0.9702 & 421.341 & 416.67 \\
Scenedesmus acuminutus & 250 & 0.0031 & 0.998 & 360.501 & 238.1 \\
& 250 & 0.000003 & 0.838 & 361.02 & 400 \\
Chlamydomonas reinhardtii & 500 & 0.0000006 & 0.898 & 926.161 & 909.091 \\
Chlorella vulgaris & 500 & 0.0000009 & 0.910 & 582.197 & 588.24 \\
Scenedesmus acuminutus & 500 & 0.0000001 & 0.938 & 681.40 & 666.67 \\
\hline
\end{tabular}

\subsection{Comparison of Different Eluents for Tl Recovery}

The recovery of $\mathrm{Tl}$ from biomass loaded with metal was tested using $\mathrm{H}_{2} \mathrm{SO}_{4}$, EDTA, $\mathrm{HCl}$ and $\mathrm{HNO}_{3}$. Low concentration of $0.1 \mathrm{M}$ was used for all cases as the biomass degenerates with increase in concentration reducing the sorption efficiency [58]. For Scenedesmus acuminutus, $\mathrm{HNO}_{3}$ recovered the highest $\mathrm{Tl}$ of up to $85.2 \%$ followed by EDTA with 74.83\%, Fig.7a. 
a)

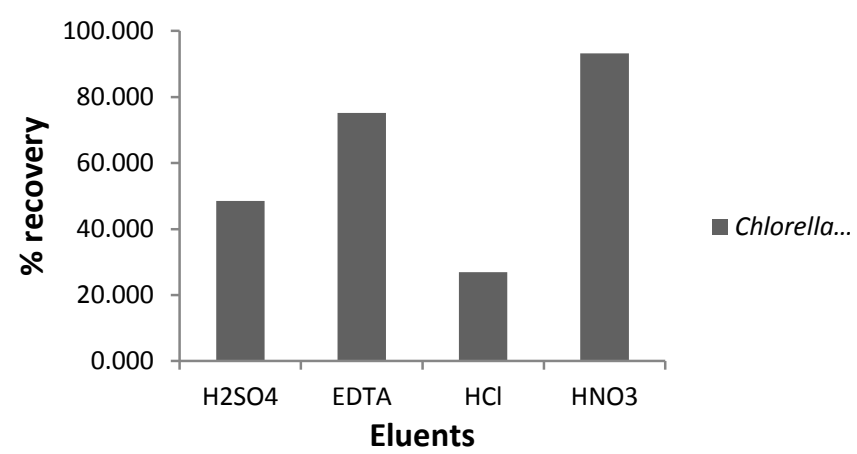

b)

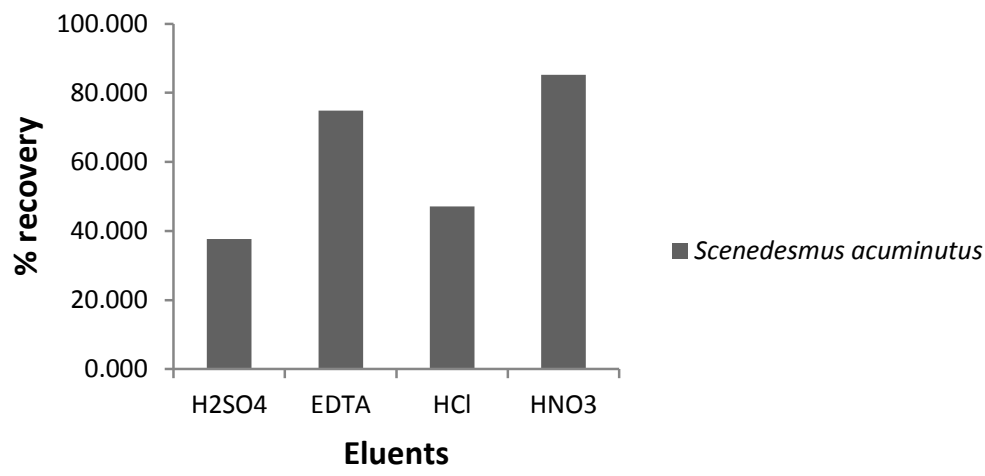

c)

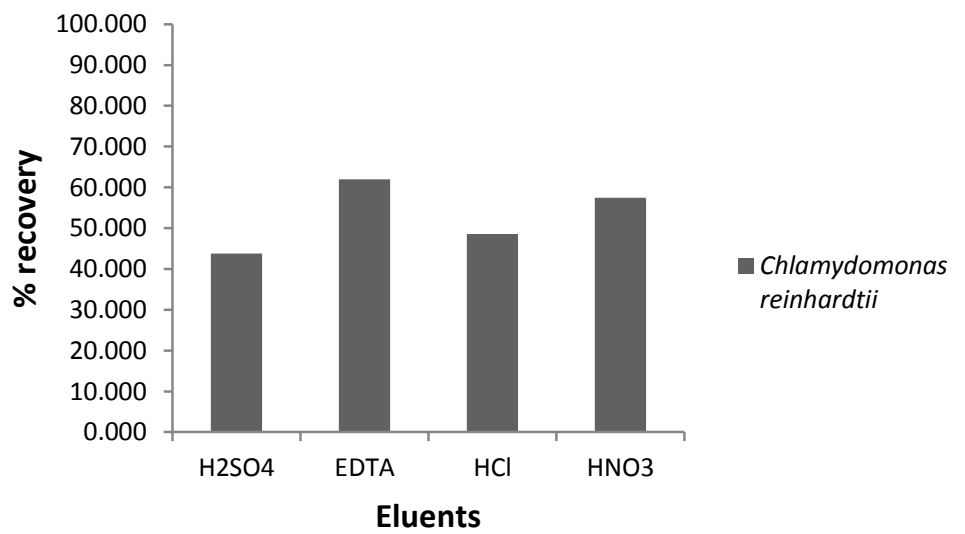

Figure 7: Comparison of different eluents for recovery of $\mathrm{Tl}$ for all the test algae

Chlorella vulgaris had the highest sorption efficiency at $93.26 \%$ followed by EDTA at $75.12 \%$, Fig. 7b. In Chlamydomonas reinhardtii, there was a slight difference in recovery 
between $\mathrm{HNO}_{3}$ and EDTA at 57.49 and $61.93 \%$ respectively, Fig.7c. In general, use of $\mathrm{HCl}$ and $\mathrm{H}_{2} \mathrm{SO}_{4}$ exhibited very low efficiencies in the recovery of Tl. The preference of eluents was in the order of $\mathrm{HNO}_{3}>$ EDTA $>\mathrm{HCl}>\mathrm{H}_{2} \mathrm{SO}_{4}$. Our results also coincide with [58], who also found $\mathrm{HNO}_{3}$ as a better desorbing agent for heavy metals.

\subsection{Surface Characterisation of Test Algae}

The SEM provided detailed information on surface topography through acquisition of a beam of electrons on the sample. All the algal samples before adsorption formed compact and
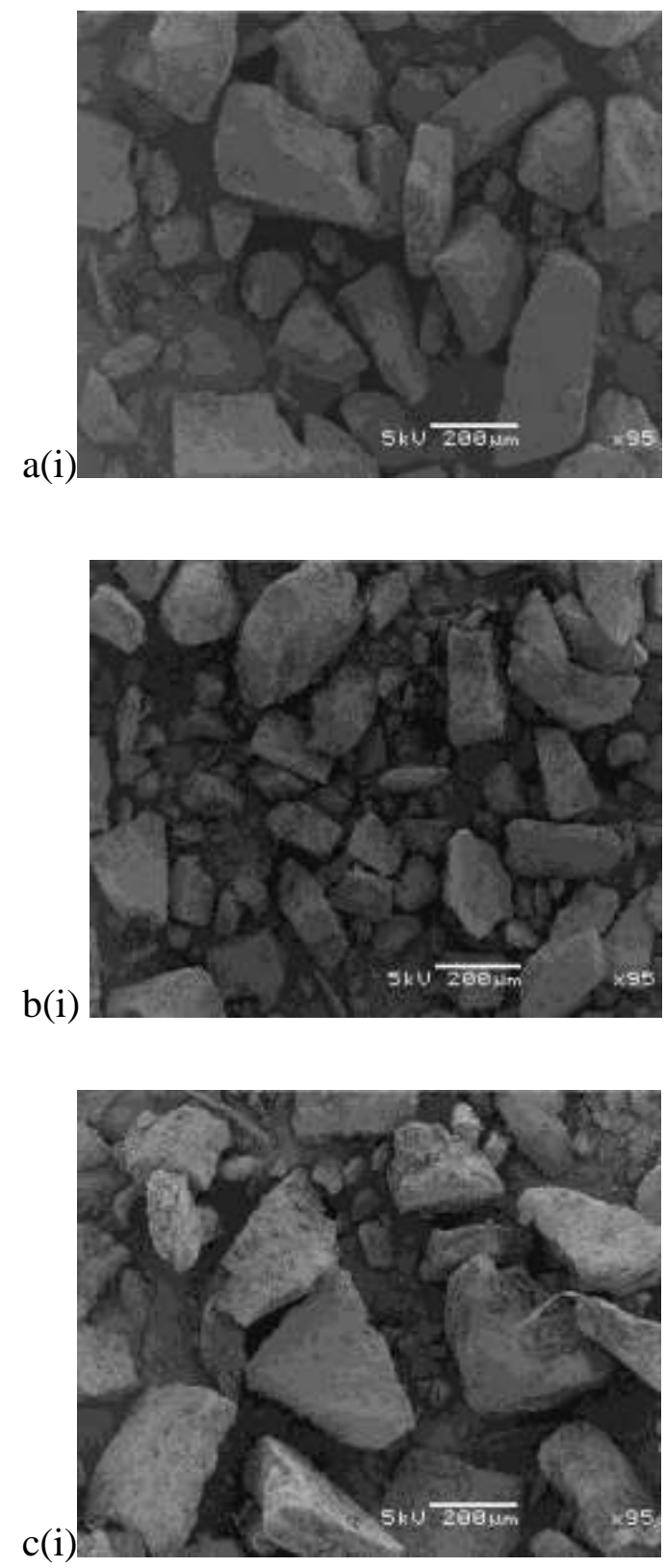

a(ii)

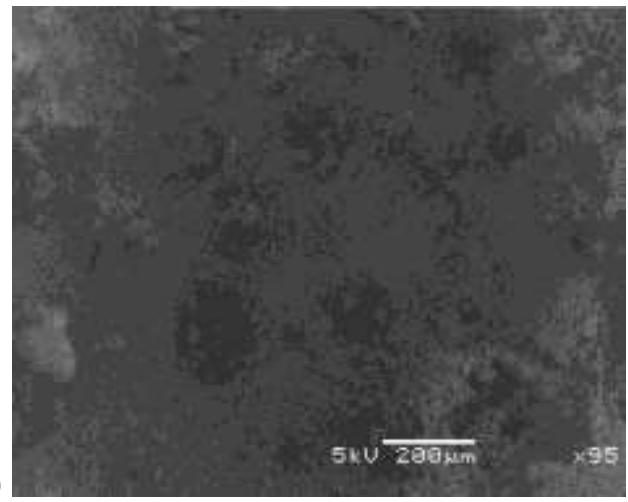

b(ii)
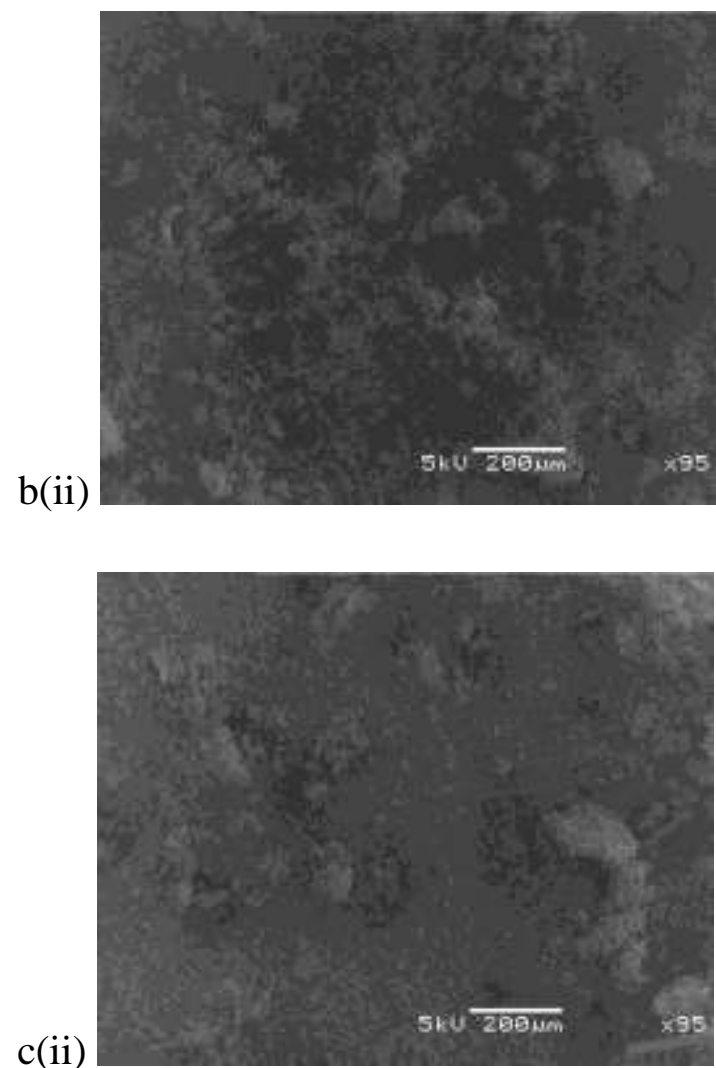

Figure 8: SEM images for a) Chlamydomonas reinhardtii, b) Chlorella vulgaris and c) Scenedesmus acuminutus- i) before, ii) after adsorption of $\mathrm{Tl}$ 
a)

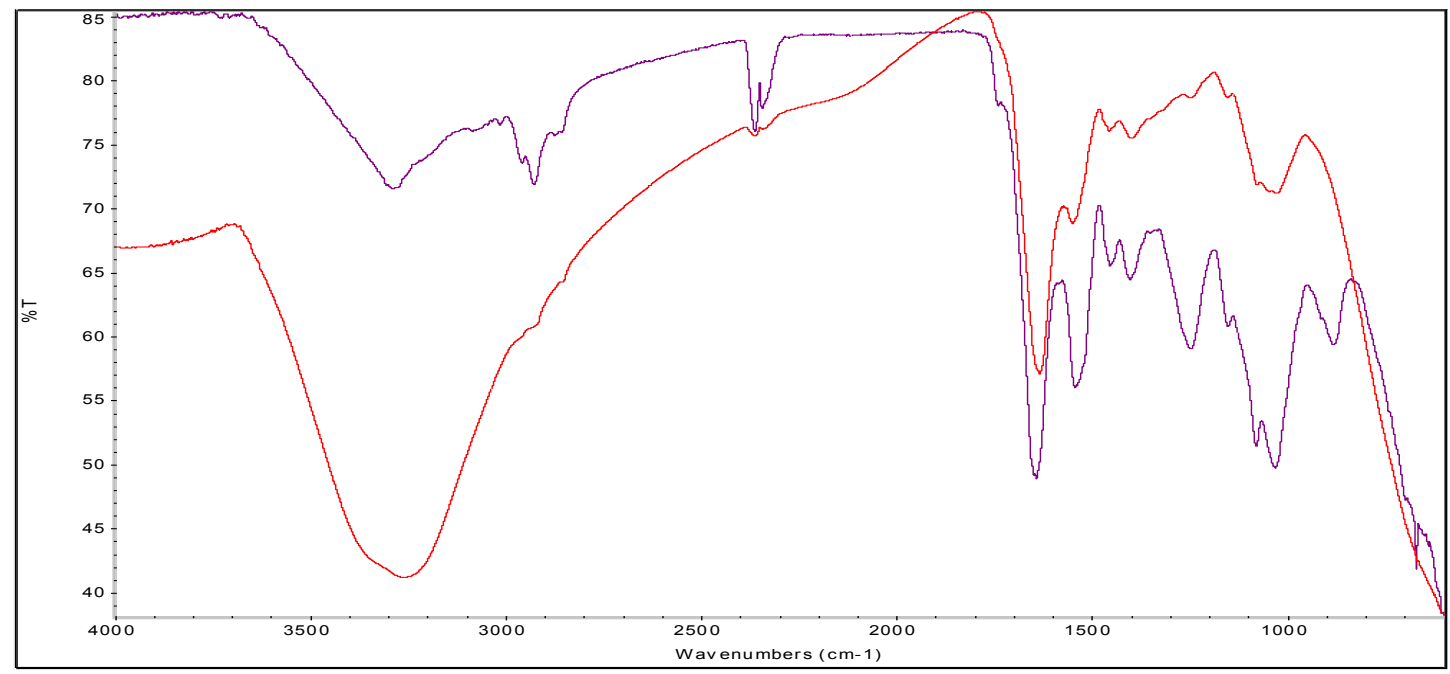

b)

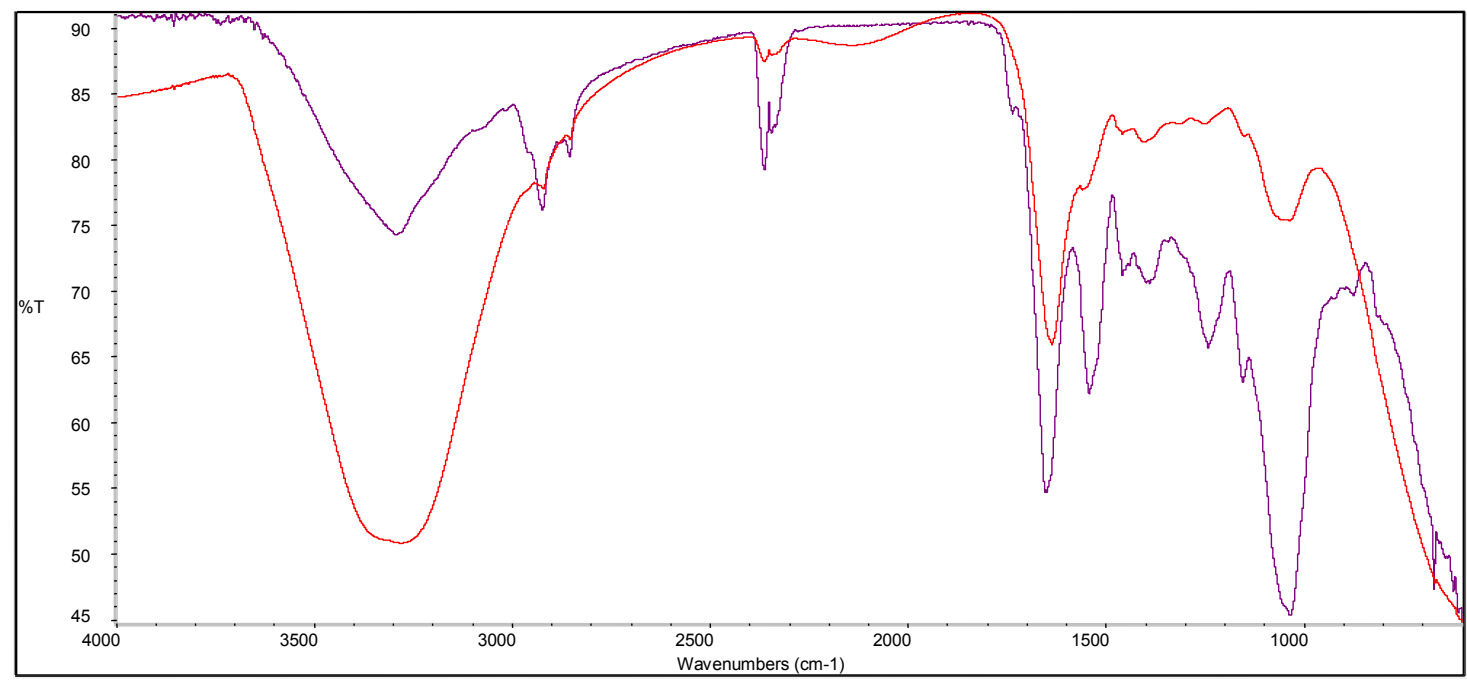

c)

d)

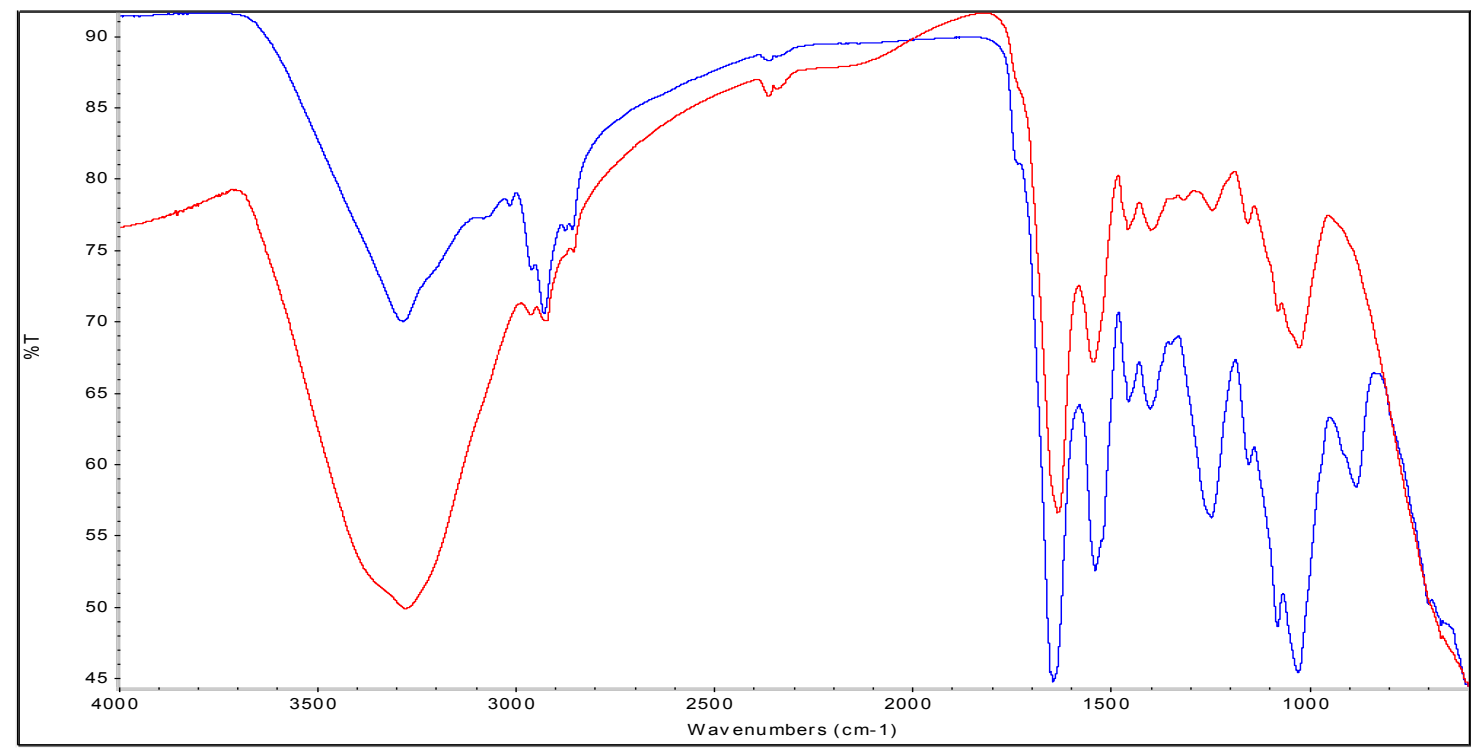

Figure 9: FTIR peaks of transmittance of $\mathrm{Tl}$ in a) Chlamydomonas reinhardtii, b) Scenedesmus acuminutus, c) Chlorella vulgaris and red representing before adsorption 
irregular surface whereas after adsorption the surface was fragmented and indication of adsorption of metals on the surface wall, Fig. 8.

For FTIR analysis, Chlamydomonas reinhardtii showed pronounced peaks at $3273.82 \mathrm{~cm}^{-1}$ before adsorption and $3293.45 \mathrm{~cm}^{-1}$ after adsorption. This indicates a very strong O-H stretch which depicts phenols and alcohols. Another stretch was between 2916.56 and $2920.48 \mathrm{~cm}^{-1}$ which is indicative of an O-H bond for carboxylic acid. Other bonds ranged from 1637-1645, $1546-1539,1024-1039.9 \mathrm{~cm}^{-1}$ representative of primary amines, nitro compounds and aliphatic amines respectively, Fig. 9a.

For Scenedesmus acuminutus and Chlorella vulgaris, there was no significant difference in peaks with the highest attained between 3289 and $3301 \mathrm{~cm}^{-1}$ reflecting primary and secondary amines and amides, Fig. 9b and c. The carboxyl stretch also appeared for the 2 species in the range of 2854-2924 $\mathrm{cm}^{-1}$. Other similar stretches were 1629-1652, 1534-1546, 1024-1048 $\mathrm{cm}^{-1}$ representing primary amines, nitro compounds and aliphatic amines respectively. It can be noted that there was slight difference in wavelength for all the species inferring similar functional groups. The differences in uptake levels were due to variations in wave numbers which influences the transmittance.

\section{Conclusion}

The potential for green micro algae tested on $\mathrm{Tl}$ showed excellent sorption capacities of $100 \%$ removal at concentrations $\geq 150 \mathrm{mg} / \mathrm{L}$ for all the tested species. Different eluents were tested with $\mathrm{HNO}_{3}$ acid emerging as the most efficient for recovery of $\mathrm{Tl}$. The recovery of $\mathrm{Tl}$ was also promising with $\geq 93 \%$ recovery for some species despite the longer period taken. The strongest functional groups responsible for $\mathrm{Tl}$ binding on the algal cell wall were carboxyl and phenols. The functional groups showed the possible mechanisms involved including ion exchange, coordination and or complexation in addition to physical adsorption. Further research is required with a combination of multi metals to reflect the actual environment before use in continuous reactors.

\section{Acknowledgements}

The authors are grateful to the University of Pretoria Commonwealth Scholarship for the financial support rendered in the completion of this project. We would also like to thank the 
technical staff and research group from the Water Utilization Division for support during this research.

\section{References}

[1] T. Xiao, F. Yang, S. Li, B. Zheng, Z. Ning, Thallium pollution in China: A geoenvironmental perspective, Sci Total Environ.421 (2012) 51-8.

[2] S. Li, T. Xiao, B. Zheng, Medical geology of arsenic, selenium and thallium in China, Sci Total Environ.421 (2012) 31-40.

[3] T. Xiao, J. Guha, D. Boyle, C. Liu, J. Chen, Environmental concerns related to high thallium levels in soils and thallium uptake by plants in southwest Guizhou, China, Sci Total Environ.318 (2004) 223-44.

[4] J.P. Mulkey, F.W. Oehme, A review of thallium toxicity, Vet Hum Toxicol. 35 (1993) 445-53.

[5] M.A.L. Antón, D.A Spears, M.D Somoano, M.R.M. Tarazona. Thallium in coal: Analysis and environmental implications, Fuel.105 (2013) 13-8.

[6] L. Ralph, M. Twiss, Comparative toxicity of thallium (I), thallium (III), and cadmium (II) to the unicellular alga Chlorella isolated from Lake Erie, Bull Environ Contam Toxicol.68(2002) 261-8.

[7] A. Busev, V. Tiptsova, Analytical chemistry of thallium. VI. New complexometric methods for the determination of thallium, Zhur.Anal.Khim, 16 (1961) 275-8.

[8] J.O Nriagu, Thallium, Chemical \& engineering news.81 (2003):153-153.

[9] S. Galván-Arzate, A. Santamaría, Thallium toxicity. Toxicol Lett.99 (1998) 1-13.

[10] U. Karlsson, Environmental levels of thallium: influence of redox properties and anthropogenic sources Örebro universitetsbibliotek (2006) ISBN: 91-7668-474-1.

[11] V. Zitko, Toxicity and pollution potential of thallium, Sci Total Environ.4(1975) 185-92.

[12] F. Herrero, E. Fernandez, J. Gomez, L. Pretel, F. Canizares, J. Frias, et al., Thallium poisoning presenting with abdominal colic, paresthesia, and irritability, Clin Toxicol.33(1995) 261-4.

[13] W.J. Meggs, R.S. Hoffman, R.D. Shih, R.S. Weisman, L.R. Goldfrank, Thallium poisoning from maliciously contaminated food, Clin Toxicol.32(1994) 723-30.

[14] J. Cavanagh, What have we learnt from Graham Frederick Young? Reflections on the mechanism of thallium neurotoxicity, Neuropathol Appl Neurobiol.17 (1991) 3-9. 
[15] A.R. Jacobson, M.B. McBride, P. Baveye, T.S Steenhuis, Environmental factors determining the trace-level sorption of silver and thallium to soils, Sci Total Environ.345(2005) 191-205.

[16] Z.M Şenol, U. Ulusoy, Thallium adsorption onto polyacryamide-aluminosilicate composites: A Tl isotope tracer study, Chem Eng J.162 (2010):97-105.

[17] G. Bidoglio, P. Gibson, M. O'Gorman, K. Roberts, X-ray absorption spectroscopy investigation of surface redox transformations of thallium and chromium on colloidal mineral oxides, Geochim Cosmochim Acta.57 (1993) 2389-94.

[18] X. Zhang, G. Yin, Z. Hu, Extraction and separation of gallium, indium and thallium with several carboxylic acids from chloride media, Talanta.59 (2003) 905-12.

[19] A. Peter, T. Viraraghavan, Thallium: a review of public health and environmental concerns, Environ Int. 31(2005) 493-501.

[20] J. Wang, C. Chen, Biosorbents for heavy metals removal and their future, Biotechnol Adv.27 (2009)195-226.

[21] D. Park, Y. Yun, J.M Park, The past, present, and future trends of biosorption, Biotechnology and Bioprocess Engineering.15 (2010):86-102.

[22] L. Duan, J. Song, X. Li, H. Yuan, N. Li, Y. Xu, Thallium concentrations and sources in the surface sediments of Bohai Bay, Mar Environ Res.73 (2012) 25-31.

[23] E. Romera, F. Gonzalez, A. Ballester, M. Blazquez, J. Munoz, Biosorption with algae: a statistical review, Crit Rev Biotechnol. 26 (2006):223-35.

[24] J.D. Wehr, Freshwater algae of North America: ecology and classification, Academic Press; (2002).

[25] R. Andersen, J. Berges, P. Harrison, M. Watanabe, Recipes for freshwater and seawater media, Algal culturing techniques.Elsevier, Amsterdam. (2005) 429-538.

[26] N. Das, R. Vimala, P. Karthika, Biosorption of heavy metals-An overview, Indian J Biotechnol.7(2008)159-69.

[27] S. Mehta, J. Gaur, Use of algae for removing heavy metal ions from wastewater: progress and prospects.,Crit Rev Biotechnol.;25(2005) 113-52.

[28] B. Volesky, Z. Holan, Biosorption of heavy metals, Biotechnol Prog.11(1995)235-50.

[29] I. Langmuir, The constitution and fundamental properties of solids and liquids. part i. solids.,J Am Chem Soc. 38(1916) 2221-95.

[30] H. Freundlich, Over the adsorption in solution, J Phys Chem. 57(1906) 1100-7.

[31] T.W. Weber, R.K. Chakravorti, Pore and solid diffusion models for fixed-bed adsorbers, AIChE J.20 (1974) 228-38. 
[32] R. Herrero Rodríguez, B. Cordero Pérez, P. Lodeiro Fernández, C. Rey Castro, S. De Vicente, M. Esteban, Interactions of Cadmium (II) and protons with dead biomass of marine algae Fucus sp., Marine Chemistry. 99(2006) 106-116.

[33] D. Kratochvil, B. Volesky, Advances in the biosorption of heavy metals, Trends Biotechnol. 16(1998) 291-300.

[34] E. Romera, F. González, A. Ballester, M. Blázquez, J. Munoz, Comparative study of biosorption of heavy metals using different types of algae, Bioresour Technol.98(2007) 334453.

[35] V. Dang, H. Doan, T. Dang-Vu, A. Lohi, Equilibrium and kinetics of biosorption of cadmium (II) and copper (II) ions by wheat straw. Bioresour Technol.100 (2009) 211-9.

[36] Y. Yang, P.J. Faustino, J.J. Progar, C.R. Brownell, N. Sadrieh, J.C. May, et al., Quantitative determination of thallium binding to ferric hexacyanoferrate: Prussian blue, Int $\mathbf{J}$ Pharm.353(2008) 187-94.

[37] R.S. Hoffman, R. Hoffman, J.A. Stringer, R.S. Feinberg, L.R. Goldfrank, Comparative efficacy of thallium adsorption by activated charcoal, Prussian blue, and sodium polystyrene sulfonate. Clin Toxicol.37(1999) 833-7.

[38] J. Zolgharnein, N. Asanjarani, T. Shariatmanesh, Removal of thallium (I) from aqueous solution using modified sugar beet pulp, Toxicological \& Environmental Chemistry. 93(2011) 207-14.

[39] A. Sheibani, M. Zare-Khormizi, Application of factorial design for adsorption of thallium (III) ion from aqueous solutions by pistachio hull, Indian J Chem Technol. 19(2012) 48-51.

[40] H.D. Khavidaki, M. Aghaie, M. Shishehbore, H. Aghaie, Adsorptive removal of thallium (III) ions from aqueous solutions using eucalyptus leaves powders, Indian J Chem Technol. 20(2013) 380-4.

[41] T. Vincent, J. Taulemesse, A. Dauvergne, T. Chanut, F. Testa, E. Guibal, Thallium (I) sorption using Prussian blue immobilized in alginate capsules, Carbohydr Polym.99 (2014) 517-26.

[42] S.Q. Memon, N. Memon, A.R. Solangi, Sawdust: A green and economical sorbent for thallium removal, Chem Eng J.140 (2008)235-40.

[43] A. Robalds, M. Klavins, L. Dreijalte, Sorption of thallium (I) ions by peat, Water Science \& Technology.68(2013) 2208-13.

[44] J. Zolgharnein, N. Asanjarani, S.N. Mousavi, Optimization and characterization of Tl (I) adsorption onto modified Ulmus carpinifolia tree leaves, CLEAN-Soil, Air, Water.39(2011) 250-8.

[45] T. Sangvanich, V. Sukwarotwat, R.J. Wiacek, R.M. Grudzien, G.E Fryxell, R.S. Addleman, et al., Selective capture of cesium and thallium from natural waters and simulated 
wastes with copper ferrocyanide functionalized mesoporous silica, J Hazard Mater.182(2010) 225-31.

[46] GZ Memon, M. Bhanger, M. Akhtar, F.N Talpur, J.R Memon, Adsorption of methyl parathion pesticide from water using watermelon peels as a low cost adsorbent, Chem Eng J. 138 (2008) 616-21.

[47] A. Sar1, M. Tuzen, Biosorption of cadmium (II) from aqueous solution by red algae, Ceramium virgatum</i>): Equilibrium, kinetic and thermodynamic studies, J Hazard Mater.157 (2008) 448-54.

[48] M. Mukhopadhyay, S. Noronha, G. Suraishkumar, Kinetic modeling for the biosorption of copper by pretreated Aspergillus niger biomass, Bioresour Technol.98 (2007)1781-7.

[49] Y. Pu, X. Yang, H. Zheng, D. Wang, Y. Su, J. He, Adsorption and desorption of thallium (I) on multiwalled carbon nanotubes. Chem Eng J.219 (2013) 403-10.

[50] S. Lagergren, About the theory of so-called adsorption of soluble substances, Kungliga Svenska Vetenskapsakademiens Handlingar.24 (1898):1-39.

[51] Y. Ho, G. McKay, Pseudo-second order model for sorption processes, Process Biochemistry.34 (1999) 451-65.

[52] O.D. Uluozlu, A. Sari, M. Tuzen, M. Soylak, Biosorption of Pb (II) and Cr (III) from aqueous solution by lichen (Parmelina tiliaceae) biomass, Bioresour Technol.99 (2008) 2972-80.

[53] A. Sarı, M. Tuzen, Kinetic and equilibrium studies of biosorption of $\mathrm{Pb}$ (II) and Cd (II) from aqueous solution by macrofungus (Amanita rubescens) biomass, J Hazard Mater. 164(2009)1004-11.

[54] R.A Anayurt, A. Sari, M. Tuzen, Equilibrium, thermodynamic and kinetic studies on biosorption of $\mathrm{Pb}$ (II) and $\mathrm{Cd}$ (II) from aqueous solution by macrofungus (Lactarius scrobiculatus) biomass, Chem Eng J.151(2009) 255-61.

[55] M. Sager, Speciation of thallium in river sediments by consecutive leaching techniques. Microchimica Acta.106 (1992) 241-51.

[56] H. Lehn, J. Schoer, Thallium-transfer from soils to plants-correlation between chemical form and plant uptake, Plant Soil. 97(1987) 253-65.

[57] E. Njikam, S. Schiewer, Optimization and kinetic modeling of cadmium desorption from citrus peels: A process for biosorbent regeneration, J Hazard Mater. 213 (2012) 242-8.

[58] K. Chojnacka, A. Chojnacki, H. Górecka, Biosorption of $\mathrm{Cr}^{3+}, \mathrm{Cd}^{2+}$ and $\mathrm{Cu}^{2+}$ ions by blue-green algae, Spirulina sp.: kinetics, equilibrium and the mechanism of the process, Chemosphere. 59 (2005) 75-84. 


\section{APPENDIX A: Experimental Data for Equilibrium Experiments}

Langmuir experimental data for Chlorella vulgaris

\begin{tabular}{|c|c|c|c|c|c|c|c|}
\hline $\begin{array}{l}\text { Initial } \\
\text { (mg/L) }\end{array}$ & $\begin{array}{l}\mathrm{Ci} \\
(\mathrm{mmol} / \mathrm{L})\end{array}$ & $\begin{array}{l}\mathrm{Ce} \\
(\mathrm{mg} / \mathrm{L})\end{array}$ & $\begin{array}{l}\mathrm{Ce} \\
(\mathrm{mmol} / \mathrm{L})\end{array}$ & $\begin{array}{l}\text { qe } \\
(\mathrm{mg} / \mathrm{g})\end{array}$ & $\begin{array}{l}\mathrm{qe} \\
\text { (mmol/L) }\end{array}$ & $\begin{array}{l}\text { ce/qe } \\
\text { (g/L) }\end{array}$ & $\begin{array}{l}\mathrm{ce} / \mathrm{qe} \\
\text { (mmol/L) }\end{array}$ \\
\hline 50 & 0.2446 & 0 & 0.0000 & 100 & 0.4893 & 0.0000 & 0.0000 \\
\hline 100 & 0.4893 & 0 & 0.0000 & 200 & 0.9786 & 0.0000 & 0.0000 \\
\hline 150 & 0.7339 & 0.3365 & 0.0016 & 299.327 & 1.4646 & 0.0011 & 0.0011 \\
\hline 250 & 1.2232 & 3.033 & 0.0148 & 493.934 & 2.4167 & 0.0061 & 0.0061 \\
\hline 500 & 2.4464 & 29.579 & 0.1447 & 940.842 & 4.6034 & 0.0314 & 0.0314 \\
\hline
\end{tabular}

Langmuir experimental data for Scenedesmus acuminutus

\begin{tabular}{|r|r|r|r|r|r|r|r|}
\hline & $\begin{array}{l}\mathrm{Ci} \\
(\mathrm{mmol} / \mathrm{L})\end{array}$ & $\begin{array}{l}\mathrm{Ce} \\
(\mathrm{mg} / \mathrm{L})\end{array}$ & $\begin{array}{l}\mathrm{Ce}( \\
\mathrm{mmol} / \mathrm{L})\end{array}$ & $\begin{array}{l}\text { qe } \\
(\mathrm{mg} / \mathrm{g})\end{array}$ & $\begin{array}{l}\text { qe } \\
(\mathrm{mmol} / \mathrm{L})\end{array}$ & $\begin{array}{l}\text { ce/qe } \\
(\mathrm{g} / \mathrm{L})\end{array}$ & $\begin{array}{l}\text { ce/qe } \\
\text { (mmol/L) }\end{array}$ \\
\hline initial & & final & & uptake & & & \\
\hline 50 & 0.2446 & 0 & 0.0000 & 100 & 0.4893 & 0.0000 & 0.0000 \\
\hline 100 & 0.4893 & 0 & 0.0000 & 200 & 0.9786 & 0.0000 & 0.0000 \\
\hline 150 & 0.7339 & 0 & 0.0000 & 300 & 1.4679 & 0.0000 & 0.0000 \\
\hline 250 & 1.2232 & 22.784 & 0.1115 & 454.432 & 2.2235 & 0.0501 & 0.0501 \\
\hline 500 & 2.4464 & 64.35 & 0.3149 & 871.3 & 4.2631 & 0.0739 & 0.0739 \\
\hline
\end{tabular}

Langmuir experimental data for Chlamydomonas reinhardtii

\begin{tabular}{|c|c|c|c|c|c|c|c|}
\hline & $\begin{array}{l}\mathrm{Ci} \\
(\mathrm{mmol} / \mathrm{L})\end{array}$ & $\begin{array}{l}\mathrm{Ce} \\
(\mathrm{mg} / \mathrm{L})\end{array}$ & $\begin{array}{l}\mathrm{Ce}( \\
\mathrm{mmol} / \mathrm{L})\end{array}$ & $\begin{array}{l}\text { qe } \\
\text { (mg/g) }\end{array}$ & $\begin{array}{l}\text { qe } \\
(\mathrm{mmol} / \mathrm{L})\end{array}$ & $\begin{array}{l}\mathrm{ce} / \mathrm{qe} \\
\mathrm{g} / \mathrm{L}\end{array}$ & $\begin{array}{l}\text { ce/qe } \\
\text { (mmol/L) }\end{array}$ \\
\hline initial & & final & & uptake & & & \\
\hline 50 & 0.2446 & 0 & 0.0000 & 100 & 0.4893 & 0.0000 & 0.0000 \\
\hline 100 & 0.4893 & 0 & 0.0000 & 200 & 0.9786 & 0.0000 & 0.0000 \\
\hline 150 & 0.7339 & 0 & 0.0000 & 300 & 1.4679 & 0.0000 & 0.0000 \\
\hline 250 & 1.2232 & 2.701 & 0.0132 & 494.598 & 2.4200 & 0.0055 & 0.0055 \\
\hline 500 & 2.4464 & 23.011 & 0.1126 & 953.978 & 4.6677 & 0.0241 & 0.0241 \\
\hline
\end{tabular}

Freundlich experimental data for Chlorella vulgaris

\begin{tabular}{|c|c|c|c|c|c|c|c|}
\hline $\begin{array}{l}\text { Initial } \\
\text { (mg/L) }\end{array}$ & $\mathrm{Ci}(\mathrm{mmol} / \mathrm{L})$ & $\begin{array}{l}\mathrm{Ce} \\
(\mathrm{mg} / \mathrm{L})\end{array}$ & $\log \mathrm{Ce}$ & $\begin{array}{l}\mathrm{Ce}( \\
\mathrm{mmol} / \mathrm{L})\end{array}$ & $\begin{array}{l}\text { qe } \\
\text { (mg/g) }\end{array}$ & log qe & $\mathrm{qe}(\mathrm{mmol} / \mathrm{L})$ \\
\hline 50 & 0.2446 & 0 & 0 & 0.0000 & 100 & 2 & 0.4893 \\
\hline 100 & 0.4893 & 0 & 0 & 0.0000 & 200 & 2.301 & 0.9786 \\
\hline 150 & 0.7339 & 0.3365 & 0 & 0.0000 & 299.327 & 2.4771 & 1.4679 \\
\hline 250 & 1.2232 & 3.033 & 0.4819 & 0.0024 & 493.934 & 2.6575 & 2.4417 \\
\hline 500 & 2.4464 & 29.579 & 1.47098 & 0.0072 & 940.842 & 2.9349 & 4.8785 \\
\hline
\end{tabular}


Freundlich experimental data for Scenedesmus acuminutus

\begin{tabular}{|r|r|r|r|r|r|r|r|}
\hline \multicolumn{1}{|l|}{ initial } & $\mathrm{Ci}(\mathrm{mmol} / \mathrm{L})$ & $\begin{array}{l}\mathrm{Ce} \\
(\mathrm{mg} / \mathrm{L})\end{array}$ & \multicolumn{1}{l|l|}{ log $\mathrm{Ce}$} & $\begin{array}{l}\mathrm{Ce}( \\
\mathrm{mmol} / \mathrm{L})\end{array}$ & $\begin{array}{l}\text { Qe } \\
(\mathrm{mg} / \mathrm{g})\end{array}$ & log qe & qe(mmol/L) \\
\hline 50 & 0.2446 & 0 & 0 & 0.0000 & 100 & 2 & 0.4893 \\
\hline 100 & 0.4893 & 0 & 0 & 0.0000 & 200 & 2.30103 & 0.9786 \\
\hline 150 & 0.7339 & 0 & 0 & 0.0000 & 300 & 2.477121 & 1.4679 \\
\hline 250 & 1.2232 & 22.784 & 1.35763 & 0.0066 & 454.432 & 2.657469 & 2.4331 \\
\hline 500 & 2.4464 & 64.35 & 1.808549 & 0.0088 & 871.3 & 2.940168 & 4.8751 \\
\hline
\end{tabular}

Freundlich experimental data for Chlamydomonas reinhardtii

\begin{tabular}{|c|c|c|c|c|c|c|c|}
\hline initial & $\begin{array}{l}\mathrm{Ci} \\
(\mathrm{mmol} / \mathrm{L})\end{array}$ & ce & $\log \mathrm{Ce}$ & $\begin{array}{l}\mathrm{Ce}( \\
\mathrm{mmol} / \mathrm{L})\end{array}$ & $\begin{array}{l}\text { qe } \\
\text { (mg/g) }\end{array}$ & $\log q$ & $\mathrm{qe}(\mathrm{mmol} / \mathrm{L})$ \\
\hline 50 & 0.2446 & 0 & 0 & 0.0000 & 100 & 2 & 0.4893 \\
\hline 100 & 0.4893 & 0 & 0 & 0.0000 & 200 & 2.301 & 0.9786 \\
\hline 150 & 0.7339 & 0 & 0 & 0.0000 & 300 & 2.477 & 1.4679 \\
\hline 250 & 1.2232 & 2.701 & 0.431525 & 0.0021 & 494.598 & 2.694 & 2.4422 \\
\hline 500 & 2.4464 & 23.011 & 1.361935 & 0.0067 & 953.978 & 2.980 & 4.8795 \\
\hline
\end{tabular}

APPENDIX B: Experimental Data for Adsorption Kinetic Experiments

Adsorption Kinetic experimental data used for Chlorella vulgaris at init. Conc. $250 \mathrm{mg} / \mathrm{L}$

\begin{tabular}{|r|l|l|}
\hline Time(t)mins & qt (mg/g) & t/q (mg.min/g) \\
\hline 0 & 491.925 & 0 \\
\hline 15 & 499.854 & 0.0300 \\
\hline 25 & 440.500 & 0.0568 \\
\hline 40 & 499.854 & 0.0800 \\
\hline 60 & 499.854 & 0.1200 \\
\hline 90 & 494.899 & 0.1819 \\
\hline 120 & 499.854 & 0.2401 \\
\hline 180 & 443.974 & 0.4054 \\
\hline 240 & 462.221 & 0.5192 \\
\hline 360 & 412.005 & 0.8738 \\
\hline
\end{tabular}


Adsorption Kinetic experimental data used for Scenedesmus acuminutus at init. Conc. $250 \mathrm{mg} / \mathrm{L}$

\begin{tabular}{|r|l|r|}
\hline Time(t)mins & qt (mg/g) & t/q (mg.min/g) \\
\hline 0 & 463.408 & 0 \\
\hline 15 & 463.802 & 0.0323 \\
\hline 25 & 474.072 & 0.0527 \\
\hline 40 & 459.705 & 0.0870 \\
\hline 60 & 424.259 & 0.1414 \\
\hline 90 & 478.277 & 0.1882 \\
\hline 120 & 444.618 & 0.2699 \\
\hline 180 & 459.114 & 0.3921 \\
\hline 240 & 422.420 & 0.5682 \\
\hline 360 & 454.432 & 0.7922 \\
\hline
\end{tabular}

Adsorption Kinetic experimental data used for Chlamydomonas reinhardtii at init. Conc. $250 \mathrm{mg} / \mathrm{L}$

\begin{tabular}{|r|r|r|}
\hline Time(t)mins & qt $(\mathrm{mg} / \mathrm{g})$ & t/q \\
\hline 0 & 470.738 & 0 \\
\hline 15 & 465.136 & 0.03225 \\
\hline 25 & 481.945 & 0.05187 \\
\hline 40 & 477.363 & 0.08379 \\
\hline 60 & 485.504 & 0.12358 \\
\hline 90 & 472.297 & 0.19056 \\
\hline 120 & 460.488 & 0.26059 \\
\hline 180 & 461.841 & 0.38974 \\
\hline 240 & 482.905 & 0.49699 \\
\hline 360 & 467.559 & 0.76996 \\
\hline
\end{tabular}

Adsorption Kinetic experimental data used for Chlorella vulgaris at init. Conc. $500 \mathrm{mg} / \mathrm{L}$

\begin{tabular}{|r|r|r|}
\hline Time(t)mins & qt $(\mathrm{mg} / \mathrm{g})$ & t/q (mg.min/g) \\
\hline 0 & 931.673 & 0 \\
\hline 15 & 997.888 & 0.0150 \\
\hline 25 & 999.854 & 0.0250 \\
\hline 40 & 982.887 & 0.0407 \\
\hline 60 & 972.961 & 0.0617 \\
\hline 90 & 964.198 & 0.0933 \\
\hline 120 & 949.375 & 0.1264 \\
\hline 180 & 956.701 & 0.1881 \\
\hline 240 & 971.905 & 0.2469 \\
\hline 360 & 958.276 & 0.3757 \\
\hline
\end{tabular}


Adsorption Kinetic experimental data used for Scenedesmus acuminutus at init. Conc. $500 \mathrm{mg} / \mathrm{L}$

\begin{tabular}{|r|l|r|}
\hline Time(t)mins & qt $(\mathrm{mg} / \mathrm{g})$ & t/q (mg.min/g) \\
\hline 0 & 919.493 & 0 \\
\hline 15 & 945.299 & 0.01587 \\
\hline 25 & 892.090 & 0.02802 \\
\hline 40 & 949.769 & 0.04212 \\
\hline 60 & 919.787 & 0.06523 \\
\hline 90 & 894.518 & 0.10061 \\
\hline 120 & 905.186 & 0.13257 \\
\hline 180 & 891.420 & 0.20193 \\
\hline 240 & 884.050 & 0.27148 \\
\hline 360 & 871.300 & 0.41318 \\
\hline & & \\
\hline
\end{tabular}

Adsorption Kinetic experimental data used for Chlamydomonas reinhardtii at init. Conc. $500 \mathrm{mg} / \mathrm{L}$

\begin{tabular}{|r|l|r|}
\hline Time $(\mathrm{t})$ mins & qt $(\mathrm{mg} / \mathrm{g})$ & t/q \\
\hline 0 & 976.590 & 0 \\
\hline 15 & 972.026 & 0.0154 \\
\hline 25 & 980.732 & 0.0255 \\
\hline 40 & 955.910 & 0.0418 \\
\hline 60 & 976.756 & 0.0614 \\
\hline 90 & 956.966 & 0.0940 \\
\hline 120 & 987.415 & 0.1215 \\
\hline 180 & 945.606 & 0.1904 \\
\hline 240 & 966.050 & 0.2484 \\
\hline 360 & 953.978 & 0.3774 \\
\hline
\end{tabular}


APPENDIX B: Experimental Data for Desorption Kinetic Experiments

Desorption Kinetic experimental data used for Chlorella vulgaris at init. Conc. $250 \mathrm{mg} / \mathrm{L}$

\begin{tabular}{|r|r|r|}
\hline time & qn $(\mathrm{mg} / \mathrm{g})$ & 1/qn \\
\hline 0 & 360.5008 & 0.002774 \\
\hline 15 & 344.3504 & 0.04356 \\
\hline 25 & 368.0802 & 0.06792 \\
\hline 40 & 357.026 & 0.112037 \\
\hline 60 & 349.2015 & 0.171821 \\
\hline 90 & 330.6992 & 0.272151 \\
\hline 120 & 348.7252 & 0.344111 \\
\hline 180 & 308.9702 & 0.58258 \\
\hline 240 & 319.2603 & 0.751738 \\
\hline 360 & 333.6809 & 1.078875 \\
\hline & & \\
\hline
\end{tabular}

Desorption Kinetic experimental data used for Scenedesmus acuminutus at init. Conc. $250 \mathrm{mg} / \mathrm{L}$

\begin{tabular}{|r|r|r|}
\hline $\mathrm{t}$ & $\mathrm{q}$ & $1 / \mathrm{q}$ \\
\hline 0 & 361.0146 & 0.00277 \\
\hline 15 & 429.2282 & 0.00233 \\
\hline 25 & 361.0602 & 0.00277 \\
\hline 40 & 377.4524 & 0.002649 \\
\hline 60 & 374.6825 & 0.002669 \\
\hline 90 & 364.3864 & 0.002744 \\
\hline 120 & 359.2621 & 0.002783 \\
\hline 180 & 338.9951 & 0.00295 \\
\hline 240 & 319.3252 & 0.003132 \\
\hline 360 & 273.0495 & 0.003662 \\
\hline
\end{tabular}

Desorption Kinetic experimental data used for Chlamydomonas reinhardtii at init. Conc. $250 \mathrm{mg} / \mathrm{L}$

\begin{tabular}{|r|r|r|}
\hline $\mathrm{t}$ min & qn & 1/qn \\
\hline 0 & 421.3407 & 0.00237 \\
\hline 15 & 425.7176 & 0.00235 \\
\hline 25 & 414.6222 & 0.00241 \\
\hline 40 & 411.3065 & 0.00243 \\
\hline 60 & 415.6741 & 0.00241 \\
\hline 90 & 396.8 & 0.00252 \\
\hline 120 & 387.2611 & 0.00258 \\
\hline 180 & 366.037 & 0.00273 \\
\hline 240 & 356.3083 & 0.00281 \\
\hline 360 & 339.7111 & 0.00294 \\
\hline & & \\
\hline
\end{tabular}


Desorption Kinetic experimental data used for Chlorella vulgaris at init. Conc. $500 \mathrm{mg} / \mathrm{L}$

\begin{tabular}{|r|r|r|}
\hline time & qn $(\mathrm{mg} / \mathrm{g})$ & 1/qn \\
\hline 0 & 582.1987 & 0.001718 \\
\hline 15 & 584.5484 & 0.001711 \\
\hline 25 & 581.3129 & 0.00172 \\
\hline 40 & 548.7632 & 0.001822 \\
\hline 60 & 553.2387 & 0.001808 \\
\hline 90 & 545.1116 & 0.001834 \\
\hline 120 & 534.4555 & 0.001871 \\
\hline 180 & 522.751 & 0.001913 \\
\hline 240 & 503.6297 & 0.001986 \\
\hline 360 & 494.1523 & 0.002024 \\
\hline
\end{tabular}

Desorption Kinetic experimental data used for Scenedesmus acuminutus at init. Conc. $500 \mathrm{mg} / \mathrm{L}$

\begin{tabular}{|c|c|c|}
\hline $\mathrm{t}$ & $q(\mathrm{mg} / \mathrm{g})$ & $1 / q n$ \\
\hline 0 & 681.3974 & 0.001468 \\
\hline 15 & 660.4948 & 0.001514 \\
\hline 25 & 678.7052 & 0.001473 \\
\hline 40 & 654.1552 & 0.001529 \\
\hline 60 & 628.1043 & 0.001592 \\
\hline 90 & 630.5017 & 0.001586 \\
\hline 120 & 618.2198 & 0.001618 \\
\hline 180 & 586.4017 & 0.001705 \\
\hline 240 & 577.3422 & 0.001732 \\
\hline 360 & 531.7871 & 0.00188 \\
\hline
\end{tabular}

Desorption Kinetic experimental data used for Chlamydomonas reinhardtii at init. Conc. $500 \mathrm{mg} / \mathrm{L}$

\begin{tabular}{|r|r|r|}
\hline $\mathrm{t}$ min & qn & 1/qn \\
\hline 0 & 926.1608 & 0.00108 \\
\hline 15 & 902.8706 & 0.00111 \\
\hline 25 & 895.7706 & 0.00112 \\
\hline 40 & 859.0882 & 0.00116 \\
\hline 60 & 889.9127 & 0.00112 \\
\hline 90 & 865.3451 & 0.00116 \\
\hline 120 & 882.8873 & 0.00113 \\
\hline 180 & 841.8618 & 0.00119 \\
\hline 240 & 825.1039 & 0.00121 \\
\hline 360 & 760.55 & 0.00131 \\
\hline
\end{tabular}


APPENDIX C: Experimental Data for Effect of Initial Concentration

\begin{tabular}{|r|r|r|l|r|r|r|r|r|}
\hline & \multicolumn{2}{|c|}{$\begin{array}{c}\text { Scenedesmus } \\
\text { acuminutus }\end{array}$} & \multicolumn{2}{|c|}{ Chlamydomonas acuminutus } & \multicolumn{2}{c|}{ Chlorella vulgaris } \\
\hline Time & $\mathbf{2 5 0} \mathbf{~} \mathbf{m g} / \mathbf{L}$ & $\mathbf{5 0 0} \mathbf{m g} / \mathbf{L}$ & & $\mathbf{2 5 0} \mathbf{m g} / \mathbf{L}$ & $\mathbf{5 0 0} \mathbf{m g} / \mathbf{L}$ & $\mathbf{2 5 0} \mathbf{m g} / \mathbf{L}$ & $\mathbf{5 0 0} \mathbf{m g} / \mathbf{L}$ \\
\hline 0 & 18.296 & 40.2535 & & 14.631 & 11.705 & 4.0375 & 34.1635 \\
\hline 15 & 18.099 & 27.3505 & & 17.432 & 13.987 & & 0.073 & 1.056 \\
\hline 25 & 12.964 & 53.955 & & 9.0275 & 9.634 & & 29.75 & 0.073 \\
\hline 40 & 20.1475 & 25.1155 & & 11.3185 & 22.045 & & 0.073 & 8.5565 \\
\hline 60 & 37.8705 & 40.1065 & & 7.248 & 11.622 & 0.073 & 13.5195 \\
\hline 90 & 10.8615 & 52.741 & & 13.8515 & 21.517 & 2.5505 & 17.901 \\
\hline 120 & 27.691 & 47.407 & & 19.756 & 6.2925 & & 0.073 & 25.3125 \\
\hline 180 & 20.443 & 54.29 & & 19.0795 & 27.197 & & 28.013 & 21.6495 \\
\hline 240 & 38.79 & 57.975 & & 8.5475 & 16.975 & & 18.8895 & 14.0475 \\
\hline $\mathbf{3 6 0}$ & 22.784 & 64.35 & & 16.2205 & 23.011 & & 43.9975 & 20.862 \\
\hline
\end{tabular}

APPENDIX D: Experimental Data for Effect of $\mathrm{pH}$

Chlamydomonas reinhardtii

\begin{tabular}{|c|c|c|c|c|c|c|}
\hline $\mathrm{pH}$ & $\begin{array}{l}\text { Initial } \\
\text { (mg/L) }\end{array}$ & C1 & $\mathrm{C} 2$ & $\begin{array}{l}\text { Final Ce } \\
(\mathrm{mg} / \mathrm{L})\end{array}$ & $* 10$ & $\mathrm{q}(\mathrm{mg} / \mathrm{g})$ \\
\hline 2 & 250 & 2.862 & 2.739 & 2.8005 & 28.005 & 277.4938 \\
\hline 4 & 250 & 0.97 & 1.012 & 0.991 & 9.91 & 300.1125 \\
\hline 5 & 250 & 0.858 & 0.871 & 0.8645 & 8.645 & 301.6938 \\
\hline 6 & 250 & 0.919 & 0.931 & 0.925 & 9.25 & 300.9375 \\
\hline 8 & 250 & 0.595 & 0.621 & 0.608 & 6.08 & 304.9 \\
\hline
\end{tabular}

Chlorella vulgaris

\begin{tabular}{|r|r|r|r|r|r|r|}
\hline $\mathrm{pH}$ & \multicolumn{1}{l|l}{$\begin{array}{l}\text { Initial } \\
(\mathrm{mg} / \mathrm{L})\end{array}$} & \multicolumn{1}{l|}{ C1 } & \multicolumn{1}{l|}{$\begin{array}{l}\text { Final Ce } \\
(\mathrm{mg} / \mathrm{L})\end{array}$} & \multicolumn{1}{l|}{ *10 } & \multicolumn{1}{l|}{ (mg/g) } \\
\hline 2 & 250 & 3.809 & 3.922 & 3.8655 & 38.655 & 264.1813 \\
\hline 4 & 250 & 1.712 & 1.806 & 1.759 & 17.59 & 290.5125 \\
\hline 5 & 250 & 2.881 & 2.848 & 2.8645 & 28.645 & 276.6938 \\
\hline 6 & 250 & 1.037 & 1.219 & 1.128 & 11.28 & 298.4 \\
\hline 8 & 250 & 1.395 & 1.226 & 1.3105 & 13.105 & 296.1188 \\
\hline
\end{tabular}

Scenedesmus acuminutus

\begin{tabular}{|r|r|r|r|r|r|r|}
\hline \multicolumn{1}{|l|l|}{ pH } & Initial (mg/L) & \multicolumn{1}{l|}{ C1 } & $\begin{array}{l}\text { Final Ce } \\
\text { (mg/L) }\end{array}$ & $* 10$ & q(mg/g) \\
\hline 2 & 250 & 3.484 & 3.45 & 3.467 & 34.67 & 269.1625 \\
\hline 4 & 250 & 1.922 & 1.949 & 1.9355 & 19.355 & 288.3063 \\
\hline 5 & 250 & 1.445 & 1.559 & 1.502 & 15.02 & 293.725 \\
\hline 6 & 250 & 1.492 & 1.46 & 1.476 & 14.76 & 294.05 \\
\hline 8 & 250 & 1.837 & 1.839 & 1.838 & 18.38 & 289.525 \\
\hline
\end{tabular}


APPENDIX E: Experimental Data for Comparison of Eluents

\begin{tabular}{|l|l|l|r|r|l|l|r|l|l|l|l|r|}
\hline & \multicolumn{5}{|c|}{ Chlamydomonas } & \multicolumn{5}{c|}{ chlorella } & \multicolumn{5}{c|}{ Scenedesmus } \\
\hline & $\mathrm{Ci}$ & $\mathrm{Cf}$ & $\mathrm{Cf} 100$ & $\% \mathrm{rec}$ & $\mathrm{Ci}$ & $\mathrm{Cf}$ & $\mathrm{Cf} * 100$ & $\% \mathrm{rec}$ & $\mathrm{ci}$ & & $\mathrm{cf}$ & $\% \mathrm{rec}$ \\
\hline $\mathrm{H}_{2} \mathrm{SO}_{4}$ & 63.5 & 0.278 & 27.8 & $\mathbf{4 3 . 8 1}$ & 60.97 & 0.296 & 29.6 & $\mathbf{4 8 . 5 5}$ & 35.28 & 0.13 & 13.3 & $\mathbf{3 7 . 7 0}$ \\
\hline $\mathrm{EDTA}$ & 63.5 & 0.393 & 39.3 & $\mathbf{6 1 . 9 3}$ & 60.97 & 0.458 & 45.8 & $\mathbf{7 5 . 1 2}$ & 35.28 & 0.26 & 26.4 & $\mathbf{7 4 . 8 3}$ \\
\hline $\mathrm{HCl}$ & 63.5 & 0.308 & 30.8 & $\mathbf{4 8 . 5 3}$ & 60.97 & 0.164 & 16.4 & $\mathbf{2 6 . 9 0}$ & 35.28 & 0.17 & 16.6 & $\mathbf{4 7 . 0 5}$ \\
\hline $\mathrm{HNO}_{3}$ & & & & $\mathbf{5 7 . 4 9}$ & & & & $\mathbf{9 3 . 2 6}$ & & & & $\mathbf{8 5 . 2 2}$ \\
\hline
\end{tabular}

APPENDIX F: Experimental Data for Effect of Contact Time on Recovery of Tl at $250 \mathrm{mg} / \mathrm{L}$

\begin{tabular}{|r|r|r|r|r|}
\hline \multicolumn{1}{|l|}{ Time } & Scenedesmus \% & Chlorella \% & Chlamydomonas \% \\
\hline 0 & 18.1737 & 4.4774 & 2.676 \\
\hline 15 & 2.7126 & 8.7568 & 1.665 \\
\hline 25 & 18.1633 & 2.4691 & 4.2279 \\
\hline 40 & 14.4479 & 5.3981 & 4.9938 \\
\hline 60 & 15.0757 & 17.4714 & 3.9849 \\
\hline 90 & 18.57094 & 12.374 & 8.3446 \\
\hline 120 & 23.1645 & 7.5976 & 10.548 \\
\hline 180 & 27.6228 & 18.1316 & 15.4504 \\
\hline 240 & 38.1115 & 15.405 & 17.6976 \\
\hline 360 & 66.7583 & 11.5839 & & 21.5314 \\
\hline 960 & 71.7379 & 63.9462 & & 25.5501 \\
\hline 1200 & 85.5221 & 79.1558 & & 40.0462 \\
\hline 1440 & & 93.2584 & & 57.4942 \\
\hline
\end{tabular}

